\title{
DISCLAIMER
}

This report was prepared as an account of work sponsored by an agency of the United States Government. Neither the United States Government nor any agency thereof, nor any of their employees, makes any warranty, express or implied, or assumes any legal liability or responsibility for the accuracy, completeness, or usefulness of any information, apparatus, product, or process disclosed, or represents that its use would not infringe privately owned rights. Reference herein to any specific commercial product, process, or service by trade name, trademark, manufacturer, or otherwise does not necessarily constitute or imply its endorsement, recommendation, or favoring by the United States Government-or any agency thereof. The views and opinions of authors expressed herein do not necessarily state or reflect those of the United States Government or any agency thereof.

\section{PVUSA Progress Report}

Project Manager: Tammie Candelario

Prepared by:

PVUSA Project Team

Technical Editing by:

\section{Wendy Ellyn}

Wm. Nesbit \& Associates

Santa Rosa, Califomia

Christina Jennings

Pacific Gas \& Electric

San Ramon, Califomia

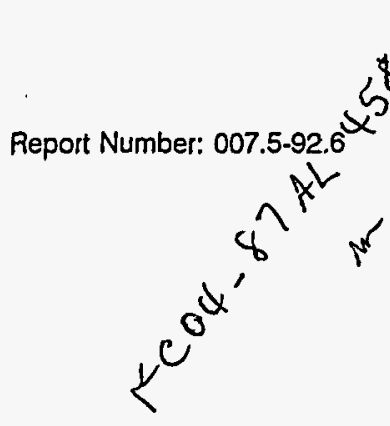




\section{DISCLAIMER}

Portions of this document may be illegible electronic image products. Images are produced from the best available original document. 


\section{ACKNOWLEDGMENTS}

The PVUSA Project Team would like to extend a special thanks to members of the PVUSA Steering Committee and Technical Review Committee for their perspectives and comments, which have made this report possible. 


\section{EXECUTIVE SUMMARY}

Photovoltaics for Utility Scale Applications (PVUSA) is a national public-private partnership that is assessing and demonstrating the viability of utility-scale photovoltaic (PV) electric generating systems. PVUSA participants include Pacific Gas \& Electric (PG\&E), the U.S. Department of Energy (DOE), the Electric Power Research Institute (EPRI), the California Energy Commission (CEC), and eight utilities and other agencies. This report updates the progress of the PVUSA project, reviews the status and performance of the various PV installations during 1991, and summarizes key findings and conclusions from work to date.

PVUSA offers utilities hands-on experience needed to evaluate and utilize maturing PV technology. The project also provides manufacturers a test bed for their products, encourages technology improvement and cost reductions in PV modules and other system components, and establishes communication channels between utilities and the PV industry. The project consists of two types of demonstrations: Emerging Module Technology (EMT) arrays, which are unproven but promising state-of-the-art PV technologies in 20-kW (nominal) arrays; and Utility Scale (US) systems, which represent more mature PV technologies in 200- to 500-kW turnkey systems.

The main EMT arrays and US systems are located at PVUSA's primary test site in Davis, California. One EMT array is located at a Maui Electric/State of Hawail host site in Maui, Hawail. The City of Austin electric utility and the New York State Energy Research and Development Authority (NYSERDA) have initiated plans for their PVUSA systems. Phase 1 of the project, begun in 1987, consists of two EMT procurements (EMT-1 and EMT-2) and one US system procurement (US-1). Phase 2, initiated in 1991, includes a third EMT procurement (EMT-3) and a second US system procurement (US-2). US-2 includes a 500-kW grid support application demonstration to be installed in 1992-1993 and connected to PG\&E's Kerman, California, substation.

Tables 1-1 and 1-2 provide a complete list of Phase 1 and Phase 2 EMT and US system suppliers, PV technologies employed, completion dates (as of June 1992), and systern sizes.

\section{ACCOMPUSHMENTS}

Specific accomplishments achieved during 1991 are listed below.

\section{Procurement, Installation, and Performance}

- Phase 1. The 20-kW ENTECH EMT-1 array was brought into operation, completing the EMT-1 installation. The ENTECH array is the first concentrator array to be installed as part of PVUSA. The ENTECH array is rated at $16.5 \mathrm{~kW}$ of $\mathrm{dc}$ power output, about 23 percent below the manufacturer's expected rating of 21.5 
$\mathrm{kW}$. The six EMT-1 arrays generated a total of $149,936 \mathrm{kWh}(\mathrm{ac})$ in 1991. An additional $94,010 \mathrm{kWh}$ was supplied by the Integrated Power Corporation (IPC) and Siemens Solar Industries (SSI) US-1 systems during start-up and testing activities. The total output was enough to satisfy the electricity requirements of about 40 homes. Annual capacity factors for the fixed-tilt arrays at Davis were about 21 to 22 percent.

Manufacturing and installation of EMT-2 and US-1 systems progressed, with completion forecast for late 1992 and early 1993. Schedule slippages of up to 31 months for the EMT-2 arrays and 26 months for the US-1 systems occurred due primarily to manufacturing delays and problems with module qualification. Satisfactory power conditioning unit (PCU) operation is an ongoing difficulty for SSI US-1, as are intermodule wiring connections for the IPC US-1 system.

- Phase 2 Procurement began for EMT-3 and US-2 systems, with completion forecast for 1994. PVUSA modified its procurement process for Phase 2 EMT arrays to include a $1-\mathrm{kW}$ test of vendors' PV technology. Tests will be supervised by Sandia National Laboratories or the National Renewable Energy Laboratory (NREL). A 10-acre site near PG\&E's Kerman substation was acquired for a 500-kW grid-support application demonstration; an RFP was issued for a mid-1993 completion date.

\section{Safety}

- Davis Site Safety. In response to an electrical shock accident involving an SSI field representative, PVUSA staff evaluated and strengthened safety procedures and practices to enhance the safety program at the PVUSA Davis site. A safety review was subsequently performed by the DOE, Brookhaven National Laboratories, the CEC, and Reynolds Electric.

\section{Technology Transfer}

- Meetings. PVUSA hosted meetings with the U.S. Technical Advisory Group of the International Electrotechnical Commission (IEC) Technical Committee 82 on Solar PV Energy Systems, and the IEEE Standards Coordinating Committee 21 (Photovoltaics). The groups discussed PV qualification and performance test standards. PVUSA provided utility perspective based on PVUSA lessons learned to date. PVUSA also hosted a technology transfer meeting and tour of the Davis site in conjunction with the SOLTECH 91 conference.

- Tours. The project team hosted tours for over 700 visitors from approximately two dozen countries. Several countries are looking at PVUSA as a model for their own PV demonstration programs. 
- Awards. PVUSA received a 1991 Environmental Achievement Special Merit Award from the National Environmental Awards Council. The project is listed in the Council's Environmental Success Index and promoted as a model environmental program.

\section{CONCLUSIONS}

PVUSA now has up to three years of operating experience with EMTs and three and a half years of prior planning, engineering, and construction experience. The project has effectively brought together federal and state agencies, national laboratories, PV suppliers, and the utility industry, and is making significant contributions in several areas of R\&D on grid-interactive PV systems. Participating utilities are learning to specify and operate PV systems, while PV vendors are learning how to supply systems to utility standards.

Although a wide discrepancy exists between manufacturers' expected dc power ratings and actual dc power ratings, EMT-1 arrays are performing well.

Schedule slippages, due primarily to manufacturing delays, module qualification difficulties, and PCU start-up problems, raise concerns about the readiness of the PV industry to deliver utility-scale, utility-grade systems. The PV industry must work closely with utilities in providing realistic schedules for PV dernonstrations.

PVUSA will continue to closely monitor and assess PV vendor performance to determine strengths, weaknesses, and areas of improvement necessary to successfully support utility demand for electric generation sources. 
. 


\section{CONTENTS}

1 Introduction $\ldots \ldots \ldots \ldots \ldots \ldots \ldots \ldots \ldots \ldots \ldots \ldots \ldots \ldots \ldots \ldots \ldots \ldots \ldots$

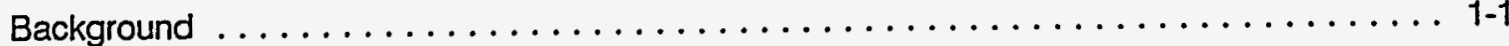

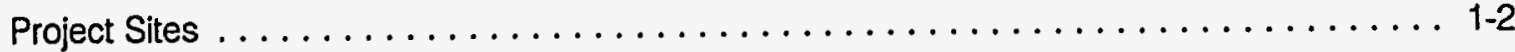

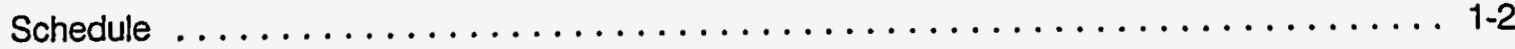

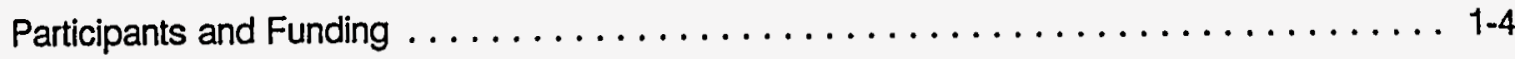

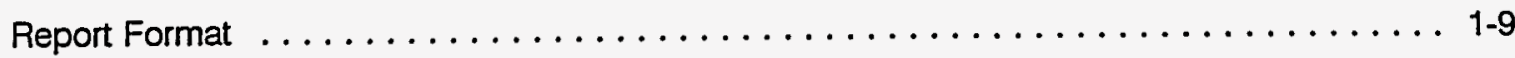

2 Procurement, Construction, and Installation $\ldots \ldots \ldots \ldots \ldots \ldots \ldots \ldots \ldots \ldots \ldots \ldots \ldots \ldots \ldots \ldots$

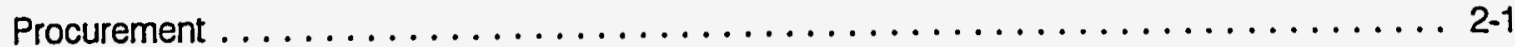

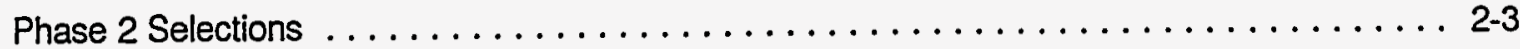

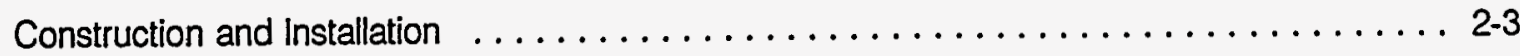

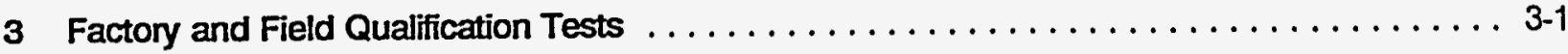

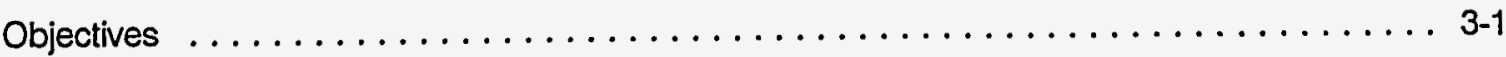

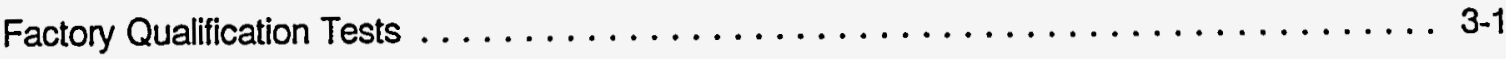

Field Wet Resistance Tests $\ldots \ldots \ldots \ldots \ldots \ldots \ldots \ldots \ldots \ldots \ldots \ldots \ldots \ldots \ldots \ldots$

Performance Tests . . . . . . . . . . . . . . . . . . . .

4 System Performance and Maintenance $\ldots \ldots \ldots \ldots \ldots \ldots \ldots \ldots \ldots \ldots \ldots \ldots \ldots .1$

Data Acquisition and Analysis $\ldots \ldots \ldots \ldots \ldots \ldots \ldots \ldots \ldots \ldots \ldots \ldots \ldots \ldots .1$

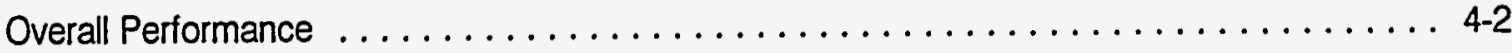

Electrical Energy Production $\ldots \ldots \ldots \ldots \ldots \ldots \ldots \ldots \ldots \ldots \ldots \ldots \ldots \ldots \ldots \ldots . . .4$

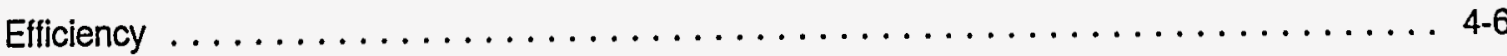

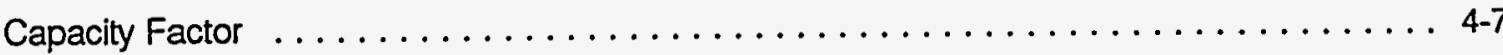

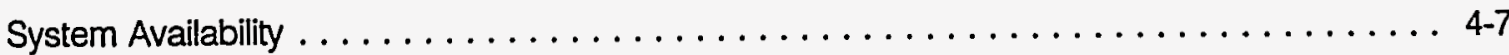

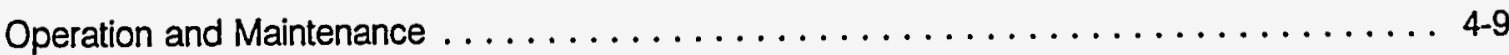

5 Special Tests and Site Safety . . . . . . . . . . . . . . .

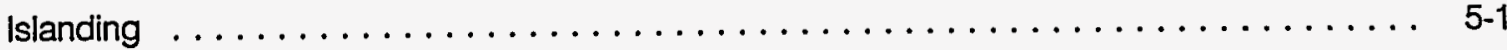

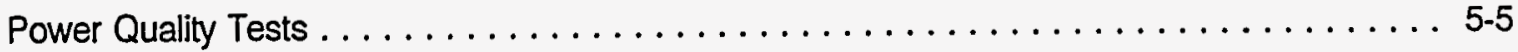

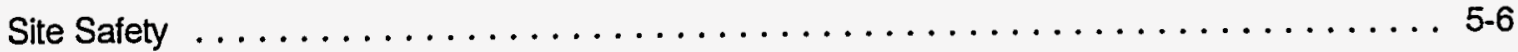

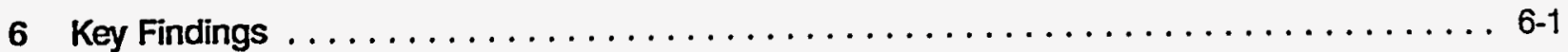

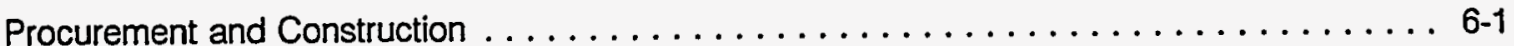

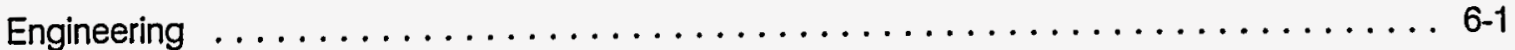

Performance ............................... 6.2 
CONTENTS (continued)

Operation and Maintenance $\ldots \ldots \ldots \ldots \ldots \ldots \ldots \ldots \ldots \ldots \ldots \ldots \ldots \ldots .6 \ldots \ldots$

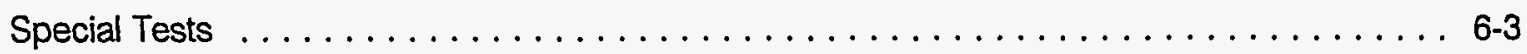

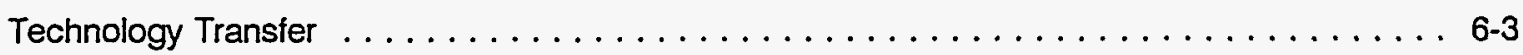

7 Conclusions and Future Work $\ldots \ldots \ldots \ldots \ldots \ldots \ldots \ldots \ldots \ldots \ldots \ldots \ldots \ldots \ldots \ldots \ldots$

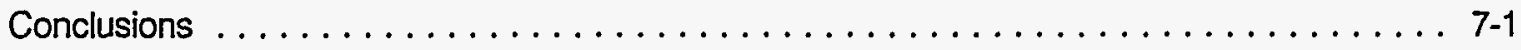

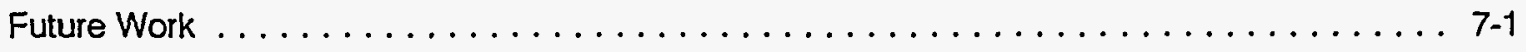

Appendix A:

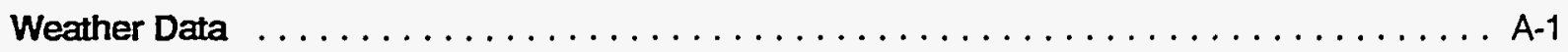
Appendix B:

Detailed Monthly Weather and Performance Summaries $\ldots \ldots \ldots \ldots \ldots \ldots \ldots$. $\ldots \ldots$ Appendix C:

Detailed 1991 O\&M Summaries $\ldots \ldots \ldots \ldots \ldots \ldots \ldots \ldots \ldots \ldots \ldots \ldots \ldots \ldots \ldots$ Appendix D:

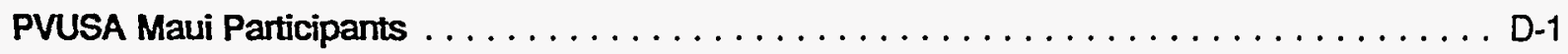
Appendix E:

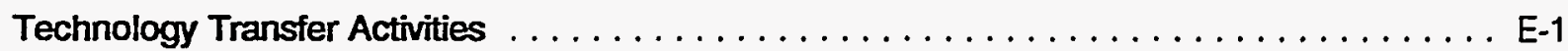
Appendix F:

Terms and Abbreviations 


\section{FIGURES}

Figure

1-1 Aerial Photograph of PVUSA Davis, May 1991

1-2 PVUSA Overall Schedule

2-1 PVUSA EMT-3 Procurement Process

4-1 PVUSA Davis Energy Production and Insolation, 1991 EMT Output

4-2 PVUSA Maui Energy Production and Insolation, 1991 EMT Output .

4-5 PVUSA EMT-1 Availabilities

5-1 PVUSA EMT-1 DECC Inverter Island Test, SSI Array - Load Fan Connected to Island Bus, Inverter Peak Power Tracking

5-2 PVUSA EMT-1 DECC Inverter Island Test, SSI and UPG Arrays - Load Fan Connected to

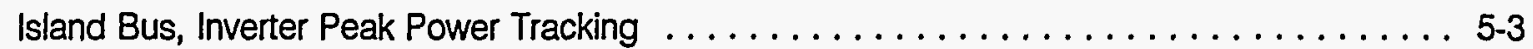

5-3 PVUSA EMT-1 DECC Inverter Island Test, SSI and UPG Arrays Connected to Grid . . . . . . 5-4

5-4 PVUSA EMT-1 DECC Inverter Characterization, SSI Array Connected to Grid . . . . . . . . 5-5

A-1 1991 PVUSA Davis Insolation . . . . . . . . . . . . . . . . . . A A 


\section{TABLES}

Table

Page

1-1 PVUSA Phase 1 Photovoltaic Systems $1-6$

1-2 PVUSA Phase 2 Photovoltaic Systems Awarded $\ldots \ldots \ldots \ldots \ldots \ldots \ldots \ldots \ldots \ldots$

$1-3$ Commitments of Funds From PVUSA Sponsors . . . . . . . . . . . . . . . . . . 1-8

2-1 Estimated Phase 1 Foundation and Support Structure Costs $\ldots \ldots \ldots \ldots \ldots \ldots \ldots$

4-1 PVUSA Installed EMT Array Characteristics $\ldots \ldots \ldots \ldots \ldots \ldots \ldots \ldots \ldots \ldots \ldots \ldots .2$

4-2 PVUSA Annual Performance Summary $\ldots \ldots \ldots \ldots \ldots \ldots \ldots \ldots \ldots \ldots \ldots \ldots \ldots$

A-1 PVUSA Davis Weather Summary $\ldots \ldots \ldots \ldots \ldots \ldots \ldots \ldots \ldots \ldots \ldots \ldots \ldots \ldots \ldots \ldots \ldots \ldots \ldots \ldots$

A-2 PVUSA Maui Weather Summary . . . . . . . . . . . . . . . . . . .

B-1 1991 PVUSA Davis Solar Resource Data . . . . . . . . . . . . . . . . . . . . . . . . . B-2

B-2 1991 PVUSA Davis Weather Data . . . . . . . . . . . . . . . . . . . . B-3

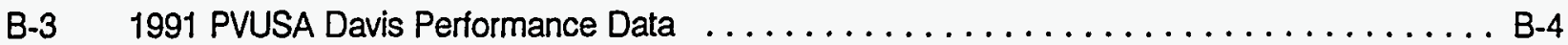

B-4 1991 PVUSA Maui Solar Resource Data . . . . . . . . . . . . . . . . . . B-6

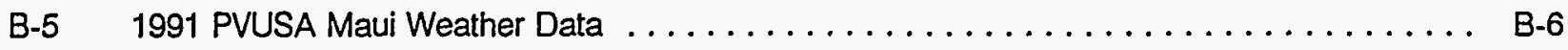

B-6 1991 PVUSA Maui Sovonics Array Performance Data . . . . . . . . . . . . . . . . . B-7

C-1 1991 PVUSA Davis Preventive Maintenance . . . . . . . . . . . . . . . . . . . . . . . . . C-1

C-2 1991 PVUSA Davis Failure-Related Activities $\ldots \ldots \ldots \ldots \ldots \ldots \ldots \ldots \ldots \ldots \ldots \ldots \ldots$ C-2

C-3 1991 PVUSA Davis Research Activities $\ldots \ldots \ldots \ldots \ldots \ldots \ldots \ldots \ldots \ldots \ldots \ldots$. . . . . . . . .

C-4 1991 PVUSA Maui Sovonics Array Failure-Related Activities $\ldots \ldots \ldots \ldots \ldots \ldots \ldots \ldots \ldots$ C-3 


\section{INTRODUCTION}

The following section provides information on PVUSA's goals and scope, technologies, project sites, schedule, participants, and funding. A more complete description of PVUSA's history and development, objectives, PV and engineering standards, and management structure can be found in the 1989-1990 PVUSA Progress Report, which is available upon request from the PVUSA project office.

\section{BACKGROUND}

With the cost of PV modules continuing to fall and environmental pressures mounting, PV could be a significant source of power by the late 1990s. However, acceptance of this technology by the utility industry requires knowledge of PV operational characteristics in a utility system and confidence in predicting the performance, reliability, and lifetime economics of PV.

PVUSA is a national public-private partnership that is assessing and demonstrating the viability of utility-scale PV electric generating systems. PVUSA offers utilities hands-on experience needed to evaluate and utilize maturing PV technology, provides manufacturers a test bed for their products, and encourages technology improvement and cost reductions in PV modules and other system components. The project also establishes the communication channels between utilities, government laboratories, and the PV industry that will be necessary for successful commercialization of utility PV systems.

In 1991, PVUSA continued to fulfill its primary goal of field testing a wide range of promising American-made PV module technologies and balance-of-system (BOS) components in a utility setting. (The term BOS refers to all equipment that is not part of the actual PV array, such as support structures, dc to ac inverters, wiring, utility grid interconnection equipment, and associated labor.)

The project consists of EMT arrays and US systems. EMTs are state-of-the-art PV module technologies that show promise but have not yet been field tested. Each EMT array selected for demonstration at PVUSA represents a substantial technical improvement or potential cost reduction over previously deployed PV technologies. The 20-kW size of the EMT arrays was selected to demonstrate ease of manufacture and allow a statistically credible evaluation, while minimizing the risks associated with a new technology.

PVUSA is fielding EMT arrays primarily to encourage promising PV module technologies out of the laboratory and into pilot production. During this evolution, the EMT manufacturer can determine if the manufacturing 
process merits further development or scale-up. The manufacturer will also have the ability to optimize nextgeneration module design based on demonstrated EMT performance and reliability at PVUSA. These lessons learned by manufacturers will be critical input for PV technology commercialization decisions. In addition, EMTs provide PVUSA with an opportunity to develop and establish procedures for performing and tracking PV system operation and maintenance, which could be used as a basis for developing corresponding procedures for the US systems.

While EMTs primarily benefit PV manufacturers, US systems offer valuable information for utilities. US systems are vendor-optimized turnkey PV systems representing mature module technologies that have the potential to produce low-cost energy and also meet the maintenance, power quality, reliability, and lifetime requirements necessary for utility applications. The US systems selected for demonstration are $200 \mathrm{~kW}$ and larger; they are expected to capture much of the economies of scale of larger systems and provide realistic evidence of system protection requirements, installation requirements and costs, system performance, operation and maintenance costs, and grid interaction. These systems incorporate innovative BOS designs that are expected to lead to cost-effective approaches for utility applications. They also provide both the project participants and the PV industry with exposure to typical commercial procurement and construction practices.

\section{PROJECT SITES}

The main EMT arrays and US systems are located at PVUSA's test site in Davis, California. Figure 1-1 presents an aerial photograph of the Davis site. Similar but smaller utility-hosted PVUSA systems are deployed at other sites in nominal ratings of $25 \mathrm{~kW}$ or greater.

In 1991, all installed EMTs and US systems were located in Davis, except for one EMT array at a Maui Electric/State of Hawaii host site. Virginia Power, NYSERDA, and the City of Austin, Texas, intend to install PVUSA systems in their areas in 1992. In addition, as part of the US-2 procurement, a 500-kW system will be installed near the PG\&E Kerman substation outside of Fresno, California, to evaluate PV's potential distribution system benefits.

\section{SCHEDULE}

The project is set up in two phases:

\section{- Phase 1}

Phase 1 is being conducted in three major stages: EMT-1, EMT-2, and US-1. Together, these systems will total about $1 \mathrm{MW}$ peak output. 


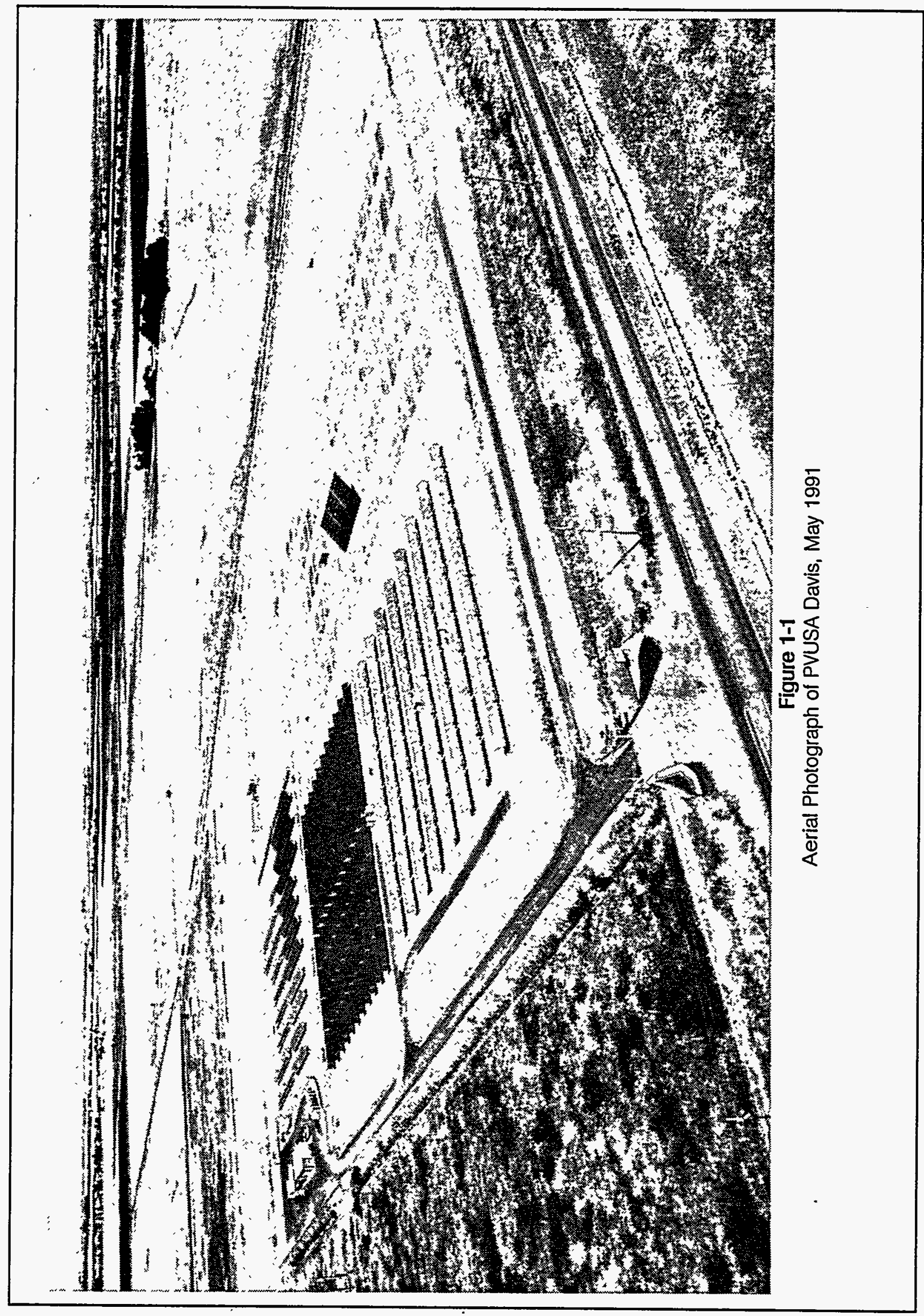


At Davis, EMT-1 consists of five 20-kW (nominal) arrays, and EMT-2 consists of three 20-kW arrays. All were, or will be, installed with PVUSA-supplied BOS components. The EMT-1 arrays were completed in early 1991; installation of the EMT-2 arrays is scheduled for 1992 and 1993. Both EMT-1 and EMT-2 arrays use identical Delta Electronic Control Corporation (DECC) Helionetics inverters of $25 \mathrm{~kW}$ nominal size.

US-1 at Davis consists of three systems, two $200-\mathrm{kW}$ and one $400-\mathrm{kW}$. By year's end, installation of all three US-1 systems was in progress.

\section{- Phase 2}

Phase 2 activities in 1991 included efforts on two stages: EMT-3 and US-2. EMT-3 includes procurement and installation of three arrays at Davis; US-2 consists of systems for both Davis and Kerman, California. The 500-kW Kerman installation was incorporated into the project by the Steering Committee in 1991. Kerman US-2 will validate PV's ability to provide grid support by relieving thermal overloads of distribution transformers and conductors. By year's end, procurement of the EMT-3 arrays and US-2 systems was initiated, with installation and evaluation scheduled for 1993-94.

Figure 1-2 provides an overall schedule of Phase 1 and Phase 2. Tables 1-1 and 1-2 provide a complete list of Phase 1 and Phase 2 EMT and US system suppliers, completion dates, PV technologies employed, and system sizes. (All completion dates in this report are as of June 1992.)

\section{PARTICIPANTS AND FUNDING}

PVUSA is a national cooperative research and development project. Participants include:

\section{Govemment Agencies/Research Institutes}

- U.S. Department of Energy

- Jet Propulsion Laboratory.

- National Renewable Energy Laboratory

- Sandia National Laboratories

- Electric Power Research Institute

- California Energy Commission

- Department of Defense Tri-Service PV Review Panel 
Phase 1 Schedule

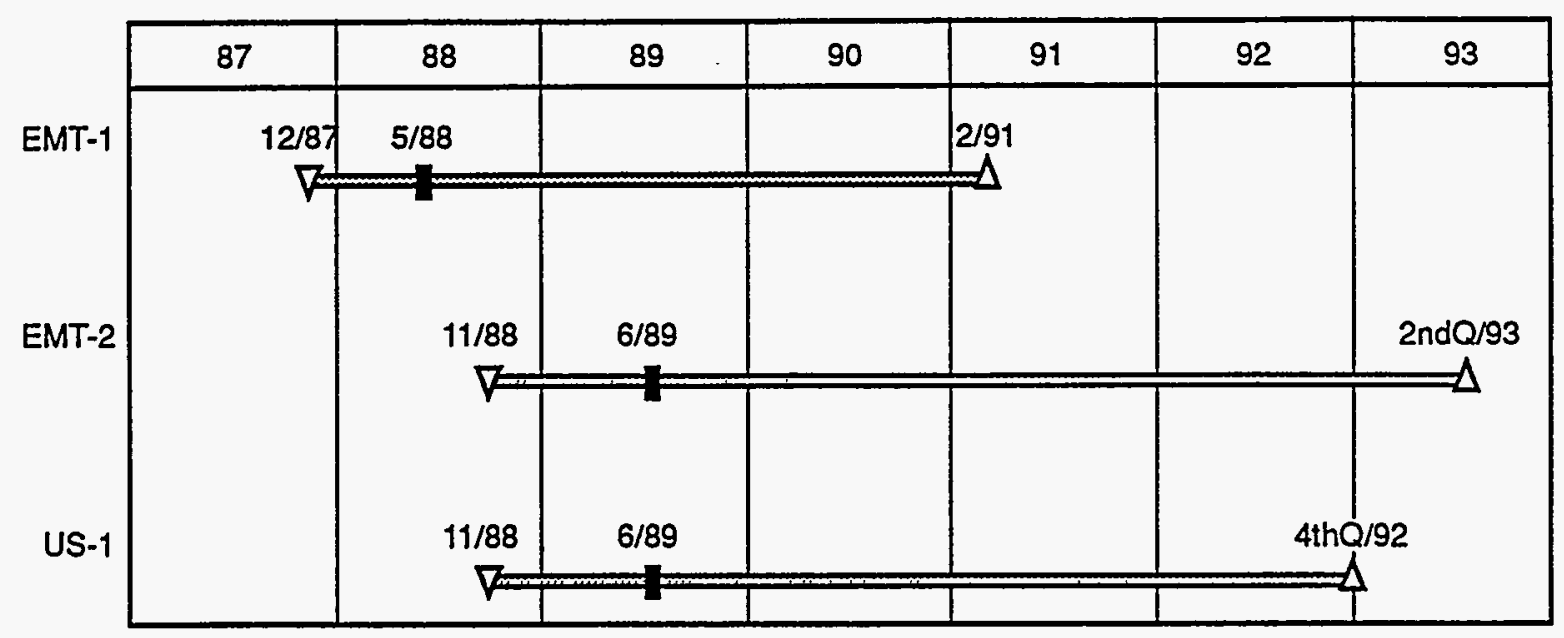

Phase 2 Schedule*

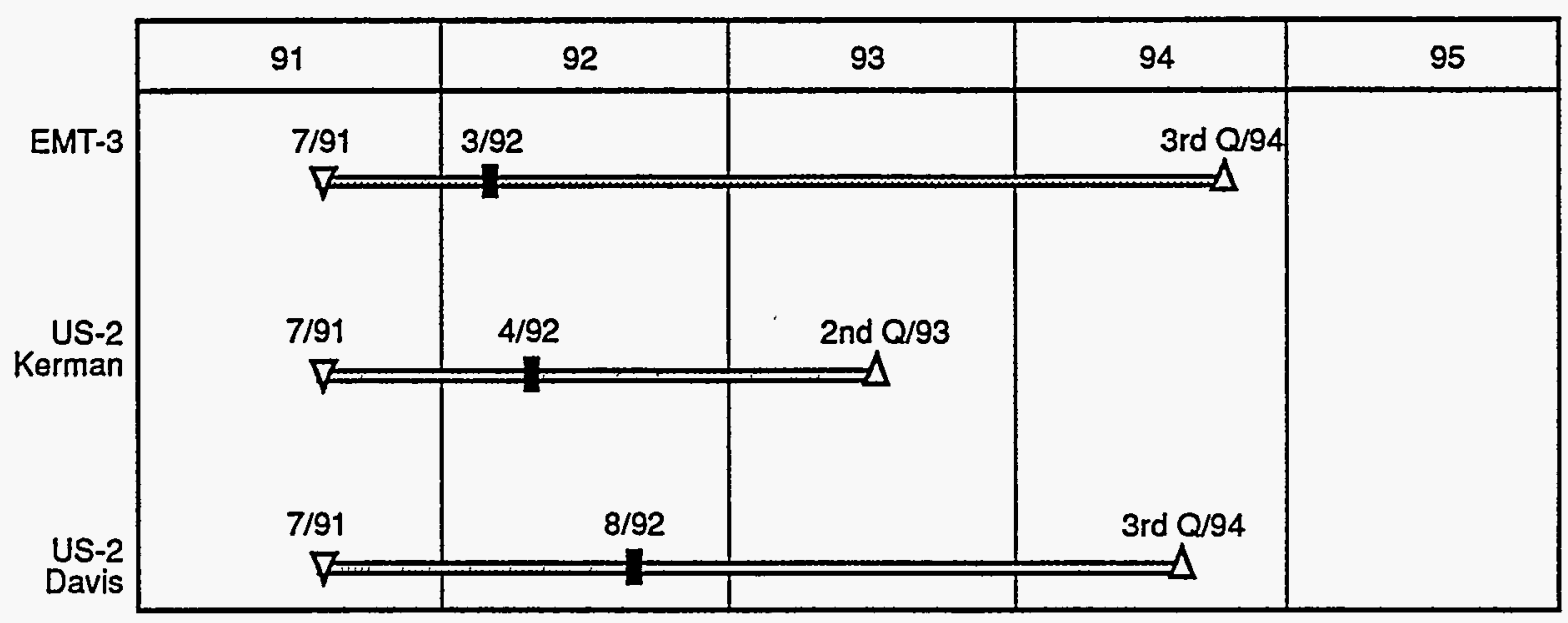

$\nabla$ Issue RFP Award Contract $\Delta$ Complete Installation

- Phase 2 future procurements to be determined

Figure 1-2

PVUSA Overall Schedule 
Table 1-1

PVUSA Phase 1 Photovoltaic Systems

\begin{tabular}{|c|c|c|c|c|}
\hline $\begin{array}{l}\text { Completion } \\
\text { Date }^{1}\end{array}$ & Supplier & Technology & $\begin{array}{c}\text { dc System } \\
\text { Efficiency } \\
(\%)^{2}\end{array}$ & $\begin{array}{l}\text { dc } \\
\text { Power } \\
(\mathbf{k W})^{2}\end{array}$ \\
\hline & EMT-1 & & & \\
\hline $1 / 89$ & Siemens Solar & Microgridded single-crystal silicon & 11.1 & 18.7 \\
\hline $6 / 89$ & Sovonics-Davis & Tandem junction amorphous silicon & 3.5 & 17.3 \\
\hline $10 / 89$ & Sovonics-Maui & Tandem junction amorphous silicon & 3.7 & 18.5 \\
\hline $12 / 89$ & Utility Power Group & Tandem junction amorphous silicon & 3.3 & 15.7 \\
\hline $10 / 90$ & Solarex & Bifacial polycrystalline silicon & 8.6 & 15.7 \\
\hline \multirow[t]{2}{*}{$3 / 91$} & ENTECH & 22x linear concentrator, crystalline silicon & 11.3 & 16.5 \\
\hline & EMT-2 & & & \\
\hline 2nd Q/93 & Siemens Solar & Copper indium diselenide & $5.5^{3}$ & $19.4^{3}$ \\
\hline 4th $Q / 92$ & AstroPower & Thin-film polycrystalline silicon on ceramic & $7.4^{3}$ & $19.3^{3}$ \\
\hline 4th $\mathrm{Q} / 92$ & Photon Energy & Cadmium telluride & $5.3^{3}$ & $18.7^{3}$ \\
\hline & & & $\begin{array}{l}\text { ac System } \\
\text { Efficiency } \\
(\%)^{2,3}\end{array}$ & $\begin{array}{c}\text { ac } \\
\text { Power } \\
(\mathrm{kW})^{2,3}\end{array}$ \\
\hline & US-1 & & & \\
\hline 4th $\mathrm{Q} / 92$ & Siemens Solar $(200 \mathrm{~kW})$ & $\begin{array}{l}\text { Single-crystal silicon, one-axis passive } \\
\text { tracking, Bluepoint PCU }\end{array}$ & 10.3 & 174 \\
\hline 4th $0 / 92$ & $\begin{array}{l}\text { Integrated Power Corp. } \\
(200 \mathrm{~kW})\end{array}$ & $\begin{array}{l}\text { Ribbon silicon (Mobil Solar EFG), one-axis } \\
\text { active tracking, Omnion PCU }\end{array}$ & 7.4 & 180 \\
\hline 3rd Q/92 & $\begin{array}{l}\text { Advanced Photovoltaic Systems } \\
(400 \mathrm{~kW})\end{array}$ & Amorphous silicon, fixed tilt, APS PCU & 3.4 & 400 \\
\hline
\end{tabular}

1 PVUSA project estimate as of June 1992.

2 Based on PVUSA TesI Conditions (PTC) and total array area, where PTC are defined as $1000 \mathrm{~W} / \mathrm{m}^{2}$ plane of array irradiance, $20^{\circ} \mathrm{C}$ ambient temperature, and $1 \mathrm{~m} / \mathrm{s}$ wind speed. (For concentrators, a direct normal irradiance of $850 \mathrm{~W} / \mathrm{m}^{2}$ is used.)

3 Based on manufacturer's estimates (systems yet to be installed). 
Table 1-2

PVUSA Phase 2 Photovoltaic Systems Awarded ${ }^{1}$

(Negotiations for these systems were under way in 1991 and contracts were awarded in 1992.)

\begin{tabular}{|c|c|c|c|c|}
\hline $\begin{array}{l}\text { Completion } \\
\text { Date }\end{array}$ & Supplier & Technology & $\begin{array}{c}\text { dc System } \\
\text { Efficiency } \\
(\%)^{2,3}\end{array}$ & $\begin{array}{c}\text { dc } \\
\text { Power } \\
(\mathrm{kW})^{2,3} \\
\end{array}$ \\
\hline & EMT-3 & & & \\
\hline 2nd $Q / 94$ & Solar Cells & Polycrystalline thin film CdTe & 7.3 & 19.7 \\
\hline 2nd Q/93 & SunPower & $\begin{array}{l}\text { 340x water-cooled, segmented parabolic dish } \\
\text { concentrator, FZ-Si back-contact cells }\end{array}$ & 15.1 & 20.0 \\
\hline 3rd Q/94 & Amonix & $\begin{array}{l}260 x \text { Fresnel point-focus concentrator, FZ-Si } \\
\text { back-contact cells }\end{array}$ & 17.8 & 20.0 \\
\hline & & & $\begin{array}{l}\text { ac System } \\
\text { Efficiency } \\
(\%)^{2,3}\end{array}$ & $\begin{array}{c}\text { ac } \\
\text { Power } \\
(k W)^{2,3} \\
\end{array}$ \\
\hline 2nd Q/93 & $\begin{array}{l}\text { US-2 } \\
\text { Siemens Solar }\end{array}$ & $\begin{array}{l}\text { Single-crystal silicon, one-axis passive } \\
\text { tracker, Omnion PCU }\end{array}$ & 9.9 & 501.9 \\
\hline
\end{tabular}

1 PVUSA projecl estimate as of June 1992.

2 Based on PVUSA Test Conditions (PTC) and total array area, where PTC are defined as $1000 \mathrm{~W} / \mathrm{m}^{2}$ plane of array irradiance, $20^{\circ} \mathrm{C}$ ambient temperature, and $1 \mathrm{~m} / \mathrm{s}$ wind speed. (For concentrators, a direct normal irradiance of $850 \mathrm{~W} / \mathrm{m}^{2}$ is used.)

3 Based on manufacturer's estimates (systems yet to be installed). 


\section{Utilities/Other Agencies}

- City of Austin, Texas, electric utility

- New York State Energy Research and Development Authority

- Niagara Mohawk

- Pacific Gas and Electric

- Salt River Project

- San Diego Gas and Electric

- State of Hawail/Maui Electric (Maui participants are listed in Appendix D.)

- Virginia Power/Commonwealth of Virginia

Additional participation by utilities and research organizations is encouraged. Memberships for PVUSA committees are available. Please contact the PVUSA project office for additional information.

The project's management structure consists of three groups: the Steering Committee (SC), which coordinates overall project direction and approves scope, schedule, and budget; the Technical Review Committee (TRC), which assesses and reviews technical aspects of the project; and the Project Team, led by PG\&E, which manages daily activities and facilitates technology transfer.

The Phase 1 budget is $\$ 19$ million. Phase 2 costs are currently estimated at $\$ 26$ million. Committed funding from PVUSA sponsors is shown in Table 1-3.

Table 1-3

Commitments of Funds From PVUSA Sponsors*

\begin{tabular}{|lcc||}
\hline Organization & $\begin{array}{c}\text { Amount } \\
\text { (millions) }\end{array}$ & Percent \\
\hline PG\&E & 11.00 & 47 \\
DOE & 9.16 & 39 \\
EPRI & 1.70 & 7 \\
CEC/California & 1.33 & 6 \\
Other Utilities & 0.23 & 1 \\
\hline Total & 23.4 & 100 \\
\hline
\end{tabular}

* Includes commitments through June 1992. 


\section{REPORT FORMAT}

This report describes PVUSA activities during 1991 and is divided into the following sections:

- Section 1 discusses PVUSA's goals and scope, technologies, project sites, schedule, participants, and funding.

- Section 2 describes 1991 procurement, construction, and installation activities, and reviews the status of all systems.

- Section 3 describes the objectives and results of factory and field qualification tests, and summarizes the results of field wet resistance and performance tests.

- Section 4 analyzes key performance areas for the six EMT-1 arrays in operation; briefly describes the PVUSA data acquisition system; summarizes overall performance for the year; analyzes energy production, efficiency, capacity factor, and system availability; and describes operation and maintenance activities.

- Section 5 describes 1991 islanding and power quality tests, and discusses site safety issues.

- Section 6 presents key findings to date in the areas of procurement, construction, engineering, performance, operation and maintenance, and technology transfer.

- Section 7 presents conclusions and recommendations for future work.

- Appendix A contains weather data.

- Appendix B contains detailed monthly weather and performance summaries.

- Appendix C contains detailed O\&M summaries.

- Appendix D lists PVUSA Maui participants.

- Appendix $E$ lists technology transfer activities.

- Appendix F contains definitions of technical terms and abbreviations that appear in this report. 


\section{Section 2}

\section{PROCUREMENT, CONSTRUCTION, AND INSTALLATION}

This section describes 1991 procurements and selections of EMT-3 and US-2 technologies, summarizes 1991 construction and installation activities, and reviews the status of all systems.

Information on PV module and system standards and design criteria adopted by PVUSA, the historical procurement process, and reasons for selection of EMT-1, EMT-2, and US-1 technologies is available in the 1989-1990 PVUSA Progress Report.

\section{PROCUREMENT}

PVUSA procurement involves significant ongoing interaction between project staff and management, vendors, and the PVUSA SC and TRC. Each PVUSA Request For Proposals (RFP) is based on lessons learned from earlier procurement cycles. In 1991, PVUSA staff met with representatives of the PV industry involved in the project to discuss how to make Phase 2 more effective to the PV industry.

As a result of the experiences gained in Phase 1, PVUSA modified the Phase 2 procurement process. The Phase 2 EMT-3 process now includes a 1-kW test of vendors' PV technology supervised by either Sandia National Laboratories or NREL after the required qualification tests. After a several-month evaluation of this 1$\mathrm{kW}$ array, the data will be presented to the PVUSA TRC and a decision will be made regarding procurement of the 20-kW system. The entire EMT-3 procurement process is illustrated in Figure 2-1.

The Phase 2 US RFP modifications include the addition of an independent design safety review of the PCU, incorporation of the most current NREL and Sandia qualification documents, and upgrade of the contractors' safety program and fire prevention and protection program requirements.

Phase 2 procurement began in 1991 for three EMT-3 arrays and two US-2 systems. By year's end, negotiations were under way with four EMT-3 vendors, three of which had been placed under contract at the time of publication of this report, while negotiations had been terminated with the fourth. A US-2 system at Davis and a US-2 system at Kerman were also bid. A decision was made late in 1991 to change the Kerman US-2 system size from $200 \mathrm{~kW}$ to $500 \mathrm{~kW}$ to better evaluate system benefits. This change required the project to reissue the RFP for $500 \mathrm{~kW}$. It also provided an opportunity to incorporate site-specific information (e.g., soil, irradiance) 


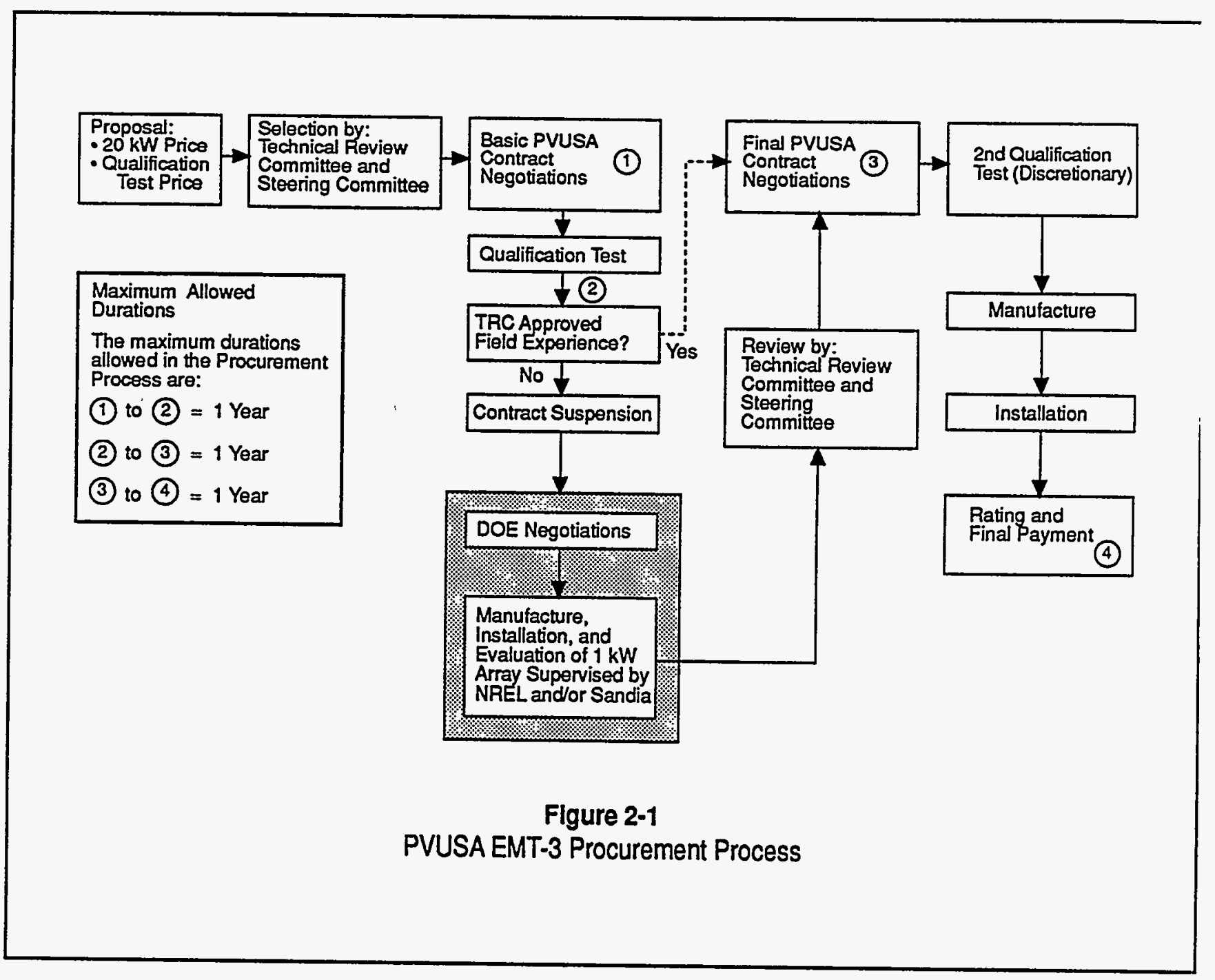


into the Kerman 500-kW RFP. At the time of publication of this report, negotiations continue on the 200-kW US-2 system for Davis.

The Phase 2 EMT-3 and US-2 vendors, their PV technologies, and system characteristics are shown in Table $1-2$.

\section{PHASE 2 SELECTIONS}

\section{EMT-3}

- SunPower

- Consists of two tracking 10-kW segmented parabolic dishes, using low-iron glass second-surface mirrors. At the focus of each dish is a receiver with 72 dense arrays of high-efficiency back-contact cells fabricated by SunPower. The $250 x$ receiver is actively cooled.

- Amonix

- Uses a high-efficiency, high-concentration array of back-contact silicon cells and an integrated back-plane for cells and wiring in a point-focus Fresnel lens module.

- Solar Cells

- Uses a cadmium telluride module produced by an experienced glass manufacturer.

US-2

- SSI (Kerman)

- Consists of 12,240 SSI M55VJ modules mounted on horizontal single-axis passive trackers that use an environmentally benign working fluid. The array consists of 17 source circuits that feed two 275-kW Omnion Series 3200 inverters, which have been improved and upgraded in packaging and technology since the PVUSA Phase 1 procurement.

\section{CONSTRUCTION AND INSTAUATION}

Progress in construction and installation was attained in the following areas:

\section{EMT-1}

- With completion of the ENTECH array in March, EMT-1 at Davis is complete, along with one EMT-1 host site array in operation on the island of Maui, Hawaii. One additional PVUSA host system installation started at Virginia Power with completion scheduled for 1992.

- The ENTECH array was rated. ENTECH is the first concentrator array to be installed at the Davis site. 
- A new 3-pole de disconnect switch was installed on each Davis EMT-1 and EMT-2 array in April. The switch furnishes a standard dc disconnect device for operator convenience and safety; standardization of emergency pushbuttons and disconnects enhances personnel safery.

Completion dates for EMT-2, US-1, and US-2 are forecasted by PVUSA as of June 1992.

\section{EMT-2}

No construction activity occurred for EMT-2 arrays due to manufacturer delays in technology development and testing. None of the EMT-2 modules successfully completed qualification testing in 1991. The PVUSA-provided BOS, including the PCU, was installed and awaited module delivery and installation for the three EMT-2 arrays.

- SSl's delivery of the modules is currently scheduled for second quarter 1993--29 months behind their original forecasted completion date. SSI reports unexpected module throughput and power stability problems.

- AstroPower's modules are currently scheduled for delivery fourth quarter 1992--30 months behind schedule. The manufacturer experienced delays in the pre-qualification testing of their modules and received PVUSA approval to complete the Virginia Power Company's PVUSA host array prior to completing the Davis array.

- Photon Energy's module delivery is currently scheduled for fourth quarter 1992-31 months behind schedule. By year's end, Photon had manufactured $4-\mathrm{ft}^{2}$ modules but had yet to reach target outputs, due primarily to funding and personnel constraints.

US-1

- SSI continued field work, primarily associated with two Bluepoint (Dickerson) inverters. The inverters experienced ongoing problems with start-up, ground fault trips, and voltage imbalances. Problems were also encountered with the system's ground fault interrupter. Completion is currently scheduled for fourth quarter 1992--26 months behind schedule.

- IPC installed trackers, modules, field interconnection wiring, and the PCU. After repairs and modifications to the tracking mechanism and wiring harnesses, IPC's system operated for one month with 10 of 11 rows of modules in service. The remaining portion of the system includes some modules whose wiring harnesses failed PVUSA's field wet resistance testing. A completion date in fourth quarter 1992 is possible--21 months behind schedule.

- After lengthy negotiations due to Chronar Corporation's bankruptcy, Advanced Photovoltaic Systems (APS) entered into a contract with PVUSA to complete the work. Installation of buried conduits, array grounding, and equipment pads was completed. Structures were erected and 240 modules were installed on the first three of 120 sections. System completion is currently scheduled for third quarter 1992--24 months behind Chronar's schedule.

- The City of Austin, Texas electric utility initiated plans for a PVUSA host system (a 25-kW IPC system scheduled for completion in 1992). 
- NYSERDA initiated plans for a PVUSA host system (also a 25-kW IPC system scheduled for completion in 1992).

US-2

- A 10-acre site at Kerman was acquired. Permitting, data acquisition system (DAS) design, and electrical system design were under way, and soils testing was completed. Results showed the site is free of toxics and suitable for foundations.

During construction of each EMT and US system, on-site PVUSA staff monitor labor and material requirements. An important aspect of PVUSA is to identify PV cost drivers and the potential to reduce them. (PVUSA staff observations provide a good basis for comparison but should not be used solely to determine the merits of any given installation.)

Costs were estimated for EMT-1, EMT-2, and US-1 foundations and support structures (Table 2-1). Foundation costs constituted about one-third to one-half of these estimated values. Although EMT costs demonstrate the relationship between PV array efficiency and total foundation and structure costs, the EMT data are of limited value when estimating costs for a larger system, since EMTs do not benefit from economies of scale.

Table 2-1

Estimated Phase 1 Foundation and Support Structure Costs

\begin{tabular}{|c|c|c|c|}
\hline & $\$ / m^{2}$ & Foundation & Support Structure \\
\hline \multicolumn{4}{|l|}{ EMT-1 } \\
\hline Fixed Arrays & 110 & Reinforced concrete caissons & Steel I-beam \\
\hline ENTECH & 260 & Reinforced concrete caissons & Steel, active two-axis tracking \\
\hline \multicolumn{4}{|l|}{ EMT-2 } \\
\hline Fixed Arrays & 125 & Pipe-embedded concrete caissons & Treated wood beam and truss \\
\hline \multicolumn{4}{|l|}{ US-1 } \\
\hline APS & 30 & Concrete caissons, soil anchors & Steel, fixed array \\
\hline IPC & 105 & Concrete caissons & Steel, active one-axis tracking \\
\hline SSI & 135 & Concrete caissons & Steel, passive one-axis tracking \\
\hline
\end{tabular}




\section{FACTORY AND FIELD QUALFICATION TESTS}

This section describes the objectives and results of factory and field qualification tests, and summarizes the results of field wet resistance and performance testing.

For more information on the PVUSA qualification test sequence, results of prior field wet resistance tests, and rating methodology, see the 1989-1990 PVUSA Progress Report.

\section{OBJECTIVES}

PVUSA has developed a set of factory and field qualification tests based on existing and proposed industry standards to ensure the safe operation and reliability of PV technologies supplied to the project. These qualification tests address durability and reliability, electrical performance, mechanical strength, safety, and corrosion resistance, and are likely to become the basis for domestic standards. In addition to meeting the requirements of PVUSA, such qualification tests will also be necessary in the longer term to satisfy utility customers that PV can be operated safely and reliably over lifetimes that are likely to exceed 20 years in most utility settings.

Principal tests and qualifying inspections include engineering review of system drawings, as-built inspection of modules, field wet resistance (wet megger) tests, field I-V curves, system functional checks (e.g., protective relays, breakers, controls), and performance test period measurements. Results of factory qualification tests, field wet resistance tests, and performance tests are described below.

\section{FACTORY QUALFICATION TESTS}

SSI's single-crystal EMT-1 and US-1 modules passed factory qualification tests prior to 1991.

IPC's US-1 modules, manufactured by Mobil Solar Energy Corporation (MSEC), started qualification testing in May 1990 with standard junction boxes. MSEC later incorporated disks and harnesses into the module design, thus eliminating the need for junction boxes. Problems with qualifying the MSEC disks and harnesses delayed completion of factory qualification tests to May 1991. After subsequent difficulties passing field qualification tests, in mid-1992 IPC proposed returning to the standard junction box design and retrofitting the modules.

APS's US-1 module production began third quarter 1991; factory qualification tests were completed in early 1992. 


\section{FIELD WET RESISTANCE TESTS}

As a measure of a system's susceptibility to corrosion and as a supplementary test of the system's safety, PVUSA conducts a field wet resistance (wet megger) test on all installed PV modules prior to system acceptance. PVUSA developed this test based on a similar Jet Propulsion Laboratory test. The PVUSA test checks the environmental seal of the PV modules and determines the level of array leakage current. Excessive leakage current can indicate premature corrosion, and, at extremes, can represent a shock hazard. The test has proven to be highly effective in detecting quality control problems in manufacturing and installation processes. In addition to the initial field wet resistance test, PVUSA periodically conducts this test on sections of each array to ensure safe, reliable operation and detect any deterioration in system components.

The results of field wet resistance tests conducted in 1991 are summarized below.

\section{ENTECH (EMT-1)}

- Tests revealed only two minor problems, both with Cam-lok "tee" connectors that showed evidence of leakage. Both passed after repair and retest. One was reoriented and one was sealed with heatshrink tubing.

\section{SSI (US-1)}

- Test results indicated several module junction boxes appeared to have hairline fractures. These were apparently due to a manufacturing defect, and not from installation. Tests also found leakage current from some bypass diodes. The leakage, which occurred at the joining of two materials used in manufacturing the unit, was repaired by SSI with silicon sealant and retested as a temporary measure while the durability of the repair is being validated. The initial failure rate on diode cases was 47 percent (7 of 15).

\section{IPC/MSEC (US-1)}

- Two and one-half of 11 rows of modules showed a greater than 9 percent failure rate due to design, manufacture, and installation errors in the module interconnecting wiring. Tests established that a leakage path into the back of the disk connectors could exist. IPC repaired failed harnesses as an interim solution and agreed to replace all harnesses. Later research uncovered evidence of generic design problems. In mid-1992, the array was disconnected and IPC proposed retrofitting the modules with standard junction boxes. 
APS (US-1)

- Tests conducted on the three installed sections showed failures in seven of 240 modules $(<3$ percent). All were related to the boot that protects the interface of the module to the output lead. APS suggested the boot problem occurred due to breakage of seals during shipping and handling, and because factory tests were not adequate to detect the design flaw. Replacement modules subsequently passed the test.

\section{PERFORMANCE TESTS}

The final step in acceptance of an EMT or US system is a 30-day performance test period. During this time, data are gathered to determine the system rating.

To calculate the expected power from a PV system under PVUSA Test Conditions (PTC), PVUSA models PV power as a function of $1000 \mathrm{~W} / \mathrm{m}^{2}$ plane of array (POA) irradiance for flat-plate modules, $850 \mathrm{~W} / \mathrm{m}^{2}$ direct normal irradiance for concentrators, $20^{\circ} \mathrm{C}$ ambient temperature, and $1 \mathrm{~m} / \mathrm{s}$ wind speed. The resulting power rating at PTC determines the payment that a supplier receives. If the PTC power rating is lower than the power rating in the supplier's bid (plus an instrument error allowance), then payment is reduced proportionately. The PTC power rating is lower than power ratings at Standard Test Conditions (STC), defined as $1000 \mathrm{~W} / \mathrm{m}^{2}$ POA irradiance, $850 \mathrm{~W} / \mathrm{m}^{2}$ direct normal for concentrators, $25^{\circ}$ or $28^{\circ} \mathrm{C}$ cell temperature, and air mass 1.5 spectrum, because the cell temperature is not constrained to $25^{\circ}$ or $28^{\circ} \mathrm{C}$. (Typical outdoor cell temperatures exceed $45^{\circ} \mathrm{C}$.)

Only ENTECH was given a full performance test in 1991. The array was rated at $16.5 \mathrm{~kW}$ dc at PTC, about 23 percent below the manufacturer's expected rating. ENTECH cited several primary reasons for the shortfall. One was that the actual cell temperatures experienced under PTC were $24^{\circ} \mathrm{C}$ higher than ENTECH expected, causing a temperature-related efficiency penalty of about 10 percent. Also, the Solarex cells supplied to ENTECH were about 12 percent below their expected efficiency. Of that shortfall, nearly half was due to a calibration factor adjustment of the Sandia reference cell used to rate the cells. Combined, these factors accounted for nearly all of the difference between the actual and expected rating.

Preliminary performance measurements indicate that the IPC US-1 system will meet or exceed proposed output targets even with the operation of only 10 of the 11 module rows. 


\section{SYSTEM PERFORMANCE AND MAINTENANCE}

The following section discusses key performance areas for the five 20-kW EMT-1 arrays operating in Davis, California, and the one array in Maui, Hawaii. It briefly describes the PVUSA DAS; summarizes overall performance for the year; updates the measures of performance presented in the 1989-1990 PVUSA Progress Report, such as energy production, efficiency, and capacity factor; provides new results on system availability; and describes operation and maintenance activities. Weather data that help characterize the sites are included in Appendix A.

For detailed information on the DAS layout and design, performance summaries for each array, and PCU operating experience prior to 1991 , see the 1989-1990 PVUSA Progress Report.

\section{DATA ACQUISITION AND ANALYSIS}

PVUSA's DAS consists of a network of Campbell Scientific data loggers--one for each PV system, one for the Davis solar/weather instruments, and one at Davis for utility grid monitoring. The data loggers for all but the US1 PV systems monitor about two dozen channels with each data scan. (For the larger US-1 systems, a greater number of similar channels will be monitored, and expanded data loggers capable of scanning over 100 input signals will be used.)

The DAS monitors ac and dc voltage, current, and power; fault current; daily ac $\mathrm{kWh}$; module and ambient temperature; POA, horizontal, direct normal, and global normal irradiance; wind speed and direction, and rainfall. The PCUs' on/off status, error off and recycle, and smoke alarms are also monitored.

Data channels are scanned every five seconds, and averaged over 10 minutes. The data are relayed to a central computer (Data Acquisition Computer), which is responsible for system control. A second identical computer (Data Display Computer), is also employed to serve as a backup if the Data Acquisition Computer fails to perform complete data processing.

To speed analysis of data, a summary program is used to compile relevant performance statistics such as energy production, solar insolation, and meteorological information. The summary program can be run over any interval of days and for any number of PV systems. 
PVUSA is evaluating the performance and capabilities of the DAS and upgrading the system to more effectively monitor future EMT and US installations.

\section{OVERALI PERFORMANCE}

The six EMT-1 arrays combined to supply 149,936 kWh (ac) in 1991. (Both SSl's and IPC's US-1 systems delivered limited energy during the latter part of 1991, while undergoing start-up tests, but were not cleared for full operation.) Through 1991, the cumulative energy produced by all of the PVUSA arrays, including start-up energy from the Davis US- 1 systems, was $439,505 \mathrm{kWh}$.

Table 4-1 outlines key features of the EMT-1 arrays discussed in this section. A three-year performance summary for these arrays appears in Table 4-2. Detailed 1991 monthly summaries are included in Appendix B.

Table 4-1

PVUSA Installed EMT Array Characteristics

\begin{tabular}{|c|c|c|c|c|c|}
\hline & SSI & $\begin{array}{l}\text { Sovonics } \\
D=\text { Davis } \\
M=\text { Maui }\end{array}$ & UPG & Solarex & ENTECH \\
\hline Orientation ${ }^{\star}$ & $30^{\circ} \mathrm{FFP}$ & $\begin{array}{l}30^{\circ} \text { FFP D } \\
22^{\circ} \text { FFP } M\end{array}$ & $30^{\circ} \mathrm{FFP}$ & $30^{\circ} \mathrm{FFP}$ & 2-ax Trk \\
\hline dc [ac] ratings $(\mathrm{kW})$ & $18.7[18.1]$ & $\begin{array}{l}17.3[15.9] D \\
18.5[17.6] M\end{array}$ & $15.7[15.1]$ & $15.7[15.1]$ & $16.5[15.6]$ \\
\hline Number of modules & 400 & $1200 D, M$ & 4992 & 336 & 60 \\
\hline Module area $\left(\mathrm{m}^{2}\right)$ & 169 & $497 D, M$ & 477 & 182 & 172 \\
\hline Array/module area & 1.01 & $1.02 D, M$ & 1.03 & 1.15 & 2.09 \\
\hline
\end{tabular}

* FFP $=$ fixed flat plate

2-ax Trk $=$ two-axis tracking 
Table 4-2

PVUSA Annual Performance Summary

\begin{tabular}{|c|c|c|c|c|}
\hline & System & 1991 & 1990 & 1989 \\
\hline ac kWh & $\begin{array}{l}\text { SSI } \\
\text { Sovonics Davis } \\
\text { Sovonics Maui } \\
\text { UPG } \\
\text { Solarex } \\
\text { ENTECH }\end{array}$ & $\begin{array}{l}31,133 \\
12,087^{\square} \\
27,319 \\
25,823 \\
26,016 \\
27,558^{\Delta}\end{array}$ & $\begin{array}{c}34,243 \\
29,037 \\
29,518 \\
29,349 \\
4,715^{+} \\
n / a\end{array}$ & $\begin{array}{c}33,391 \\
25,034 \\
5,713 \\
4,559 \\
\text { n/a } \\
\text { n/a }\end{array}$ \\
\hline dc efficiency (\%) & $\begin{array}{l}\text { SSI } \\
\text { Sovonics Davis } \\
\text { Sovonics Maui } \\
\text { UPG } \\
\text { Solarex } \\
\text { ENTECH }\end{array}$ & $\begin{array}{c}10.4 \\
2.9^{a} \\
3.4 \\
3.0 \\
8.2 \\
11.2^{\Delta}\end{array}$ & $\begin{array}{c}10.6 \\
3.1 \\
3.7 \\
3.2 \\
8.8^{+} \\
\mathrm{n} / \mathrm{a}\end{array}$ & $\begin{array}{r}10.7 \\
3.3 \\
3.7 \\
\mathrm{n} / \mathrm{a} \\
\mathrm{n} / \mathrm{a} \\
\mathrm{n} / \mathrm{a}\end{array}$ \\
\hline ac capacity factor (\%) & $\begin{array}{l}\text { SSI } \\
\text { Sovonics Davis } \\
\text { Sovonics Maui } \\
\text { UPG } \\
\text { Solarex } \\
\text { ENTECH }^{*}\end{array}$ & $\begin{array}{c}19.7 \\
8.7^{\square} \\
17.7 \\
19.5 \\
19.7 \\
26.8^{\triangle}\end{array}$ & $\begin{array}{l}21.7 \\
20.9 \\
19.1 \\
22.3 \\
17.8^{+} \\
\mathrm{n} / \mathrm{a}\end{array}$ & $\begin{array}{r}21.7 \\
21.8 \\
21.4 \\
\mathrm{n} / \mathrm{a} \\
\mathrm{n} / \mathrm{a} \\
\mathrm{n} / \mathrm{a}\end{array}$ \\
\hline Availability (\%) & $\begin{array}{l}\text { SSI } \\
\text { Sovonics Davis } \\
\text { Sovonics Maui } \\
\text { UPG } \\
\text { Solarex } \\
\text { ENTECH }\end{array}$ & $\begin{array}{l}80 \\
35^{a} \\
71 \\
83 \\
76 \\
69^{4}\end{array}$ & $\begin{array}{l}83 \\
80 \\
74 \\
86 \\
83^{+} \\
\mathrm{n} / \mathrm{a} \\
\end{array}$ & $\begin{array}{l}n / a \\
n / a \\
n / a \\
n / a \\
n / a \\
n / a\end{array}$ \\
\hline
\end{tabular}

- Sovonics Davis array inoperative since June 1991. See p. 4-10 for details.

+ Solarex 1990 data based on three months.

$\triangle$ ENTECH 1991 data based on nine months (array completed in March 1991).

- ENTECH performance based on direct normal, not global plane-of-array insolation.

\section{ELECTRICAL ENERGY PRODUCTION}

Electrical energy production generally follows the trend in insolation, except that the electrical energy production also reflects outages, limited operation during installation and start-up, and seasonal efficiency variations.

Figure 4-1 tracks the monthly ac energy produced by each Davis array during 1991. Figure 4-2 shows corresponding data for the Maui array. Referenced to the right scale of both figures are lines showing POA insolation (this quantity was integrated over all hours) and, for Davis, the estimated long-term monthly average 


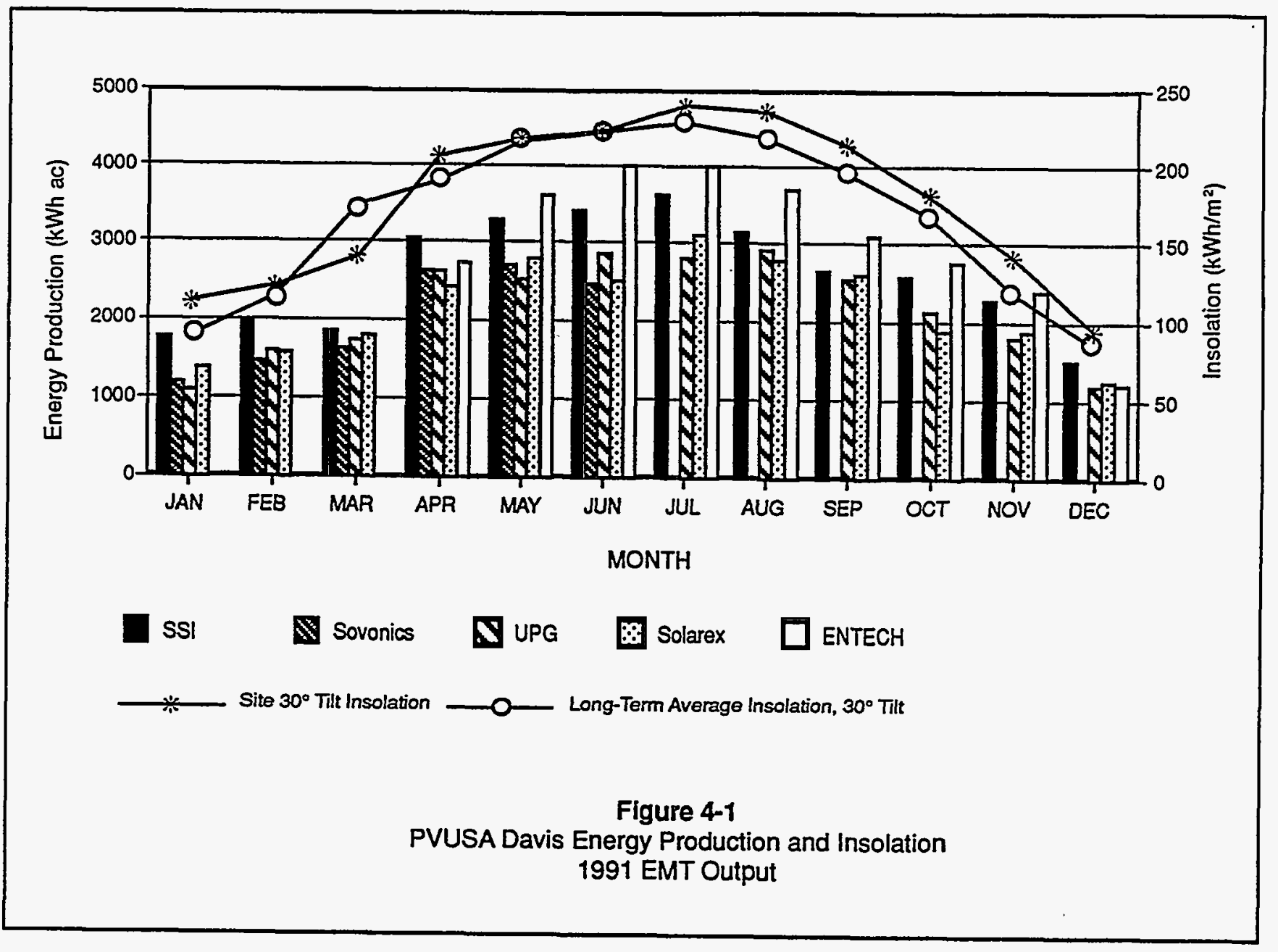




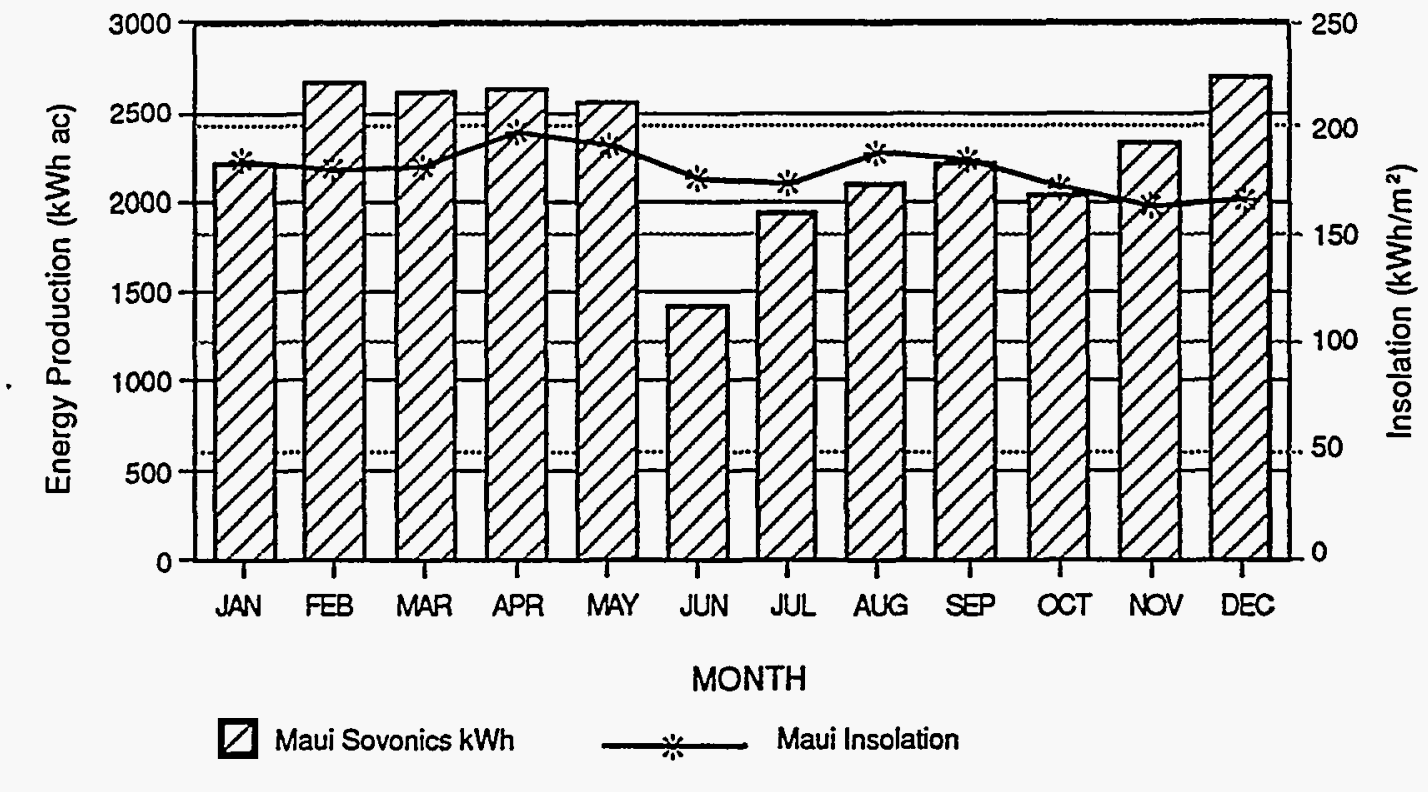

Figure 4-2

PVUSA Maui Energy Production and Insolation 1991 EMT Output

$30^{\circ}$ POA insolation. The measured $30^{\circ}$ tilt insolation in Davis was 4.6 percent greater than the estimated longterm average $30^{\circ}$ insolation. Long-term average data are not available for the Maui site.

For Davis, the array monthly energy production pattern varies fairly smoothly between 1000 and 4000 $\mathrm{kWh} / \mathrm{month}$, with a site average of about $2000 \mathrm{kWh} / \mathrm{month}$. Data for the Sovonics Davis array were not available for the last six months of 1991 because of an array source circuit junction box failure that occurred at the end of June. The array resumed operation in July 1992.

Monthly energy production at the Maui site was more consistent than that at Davis and averaged about 2300 $\mathrm{kWh} /$ month. Energy production did not track with the insolation trend line during June 1991 on Figure 4-2 for the Maui Sovonics array. During June 1991, the array output was reduced by 44 percent because the PCU was frequently off line and several modules had failed. The array's PCU tripped off line and had to be reset manually 32 times during 1991. Most of these trips were due to grid disturbances. Several trips occurred on weekends, resulting in extended downtime. 


\section{EFFICIENCY}

Efficiency for all arrays except the ENTECH array is calculated as the ratio of monthly dc energy produced to monthly POA insolation during hours when the PCU is operating. The ENTECH array, which uses a $22 x$ concentrating lens and two-axis tracking structure, partially shades itself and its pyrheliometer during the early and late hours of the day. Therefore, its efficiency calculations are based on data collected between 9 a.m. and 3 p.m. PST, when shading does not occur.

Figure 4-3 shows each array's monthly average dc efficiency, beginning in 1989. The three amorphous silicon arrays--Sovonics Davis, Sovonics Maui, and Utility Power Group (UPG)--have demonstrated dc efficiencies of about 3 percent, with the Maui array tending to be about 15 percent higher than the other two arrays. There are no data to report for the Davis Sovonics array during the second half of 1991 because of the junction box failure noted earlier.

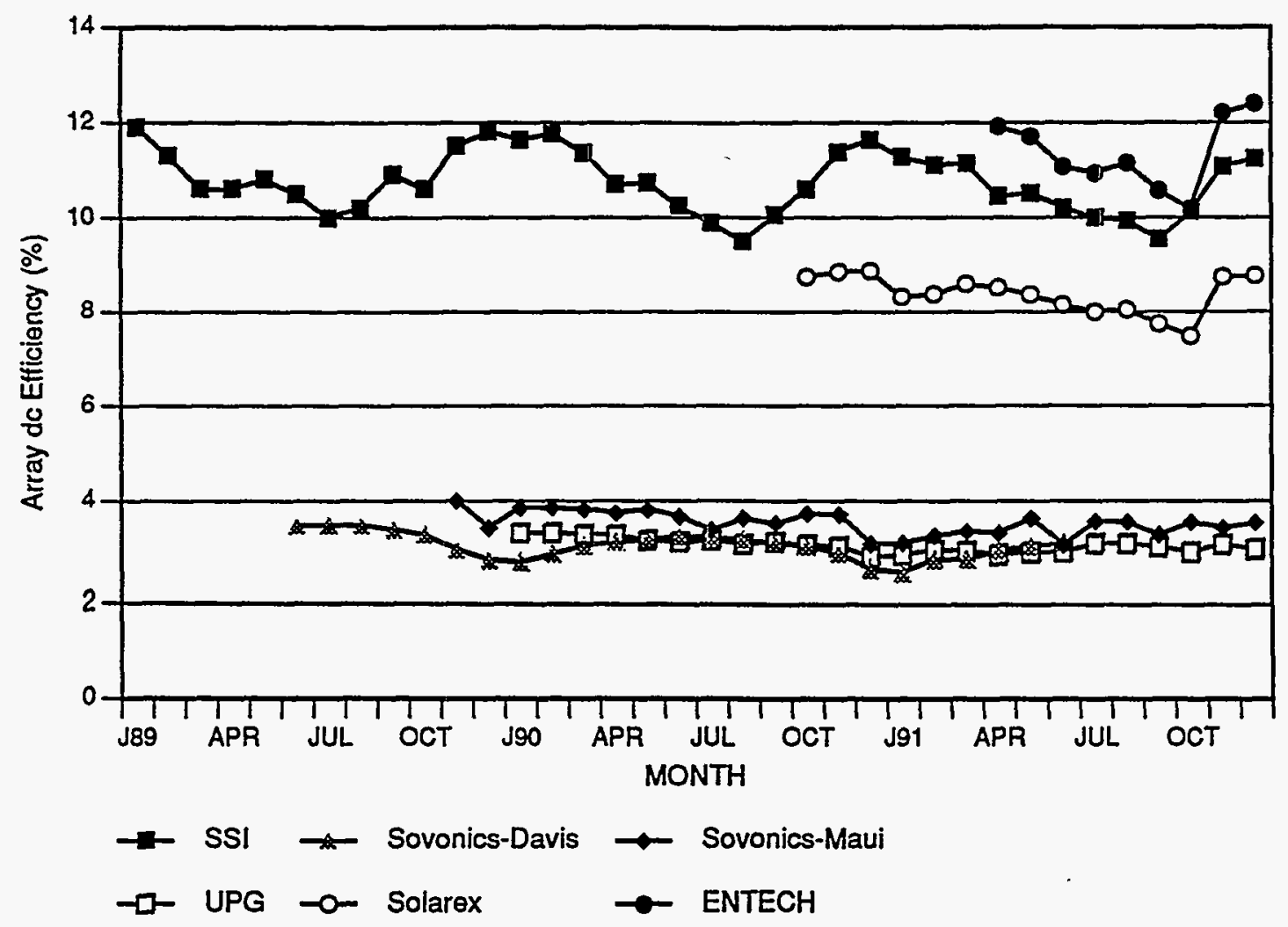

Figure 4-3

PVUSA dc Efficiencies 
The Maui array's better performance has been attributed to the incorporation of a few post-Davis design improvements such as changes in the laminating process. Another possible factor is that the spectral distribution of irradiance at Maui may be both steadier and more favorable for amorphous silicon modules, which do not respond as well to infrared irradiance. This hypothesis will be tested in 1992 by monitoring the infrared component of irradiance as well as the full spectrum, and comparing the monthly proportion of infrared insolation at Maui and Davis.

Solarex polycrystalline silicon and ENTECH and SSI single-crystal silicon arrays have demonstrated dc array efficiencies ranging from 8 percent to 12 percent, with a relative seasonal swing of about 20 percent for each (winter highest, summer lowest). This is a commonly observed pattern due principally to variations in temperature.

\section{CAPACTY FACTOR}

Capacity factor is calculated as the ratio of monthly ac energy $(\mathrm{kWh})$ divided by the product of the ac rating $(\mathrm{kW})$ as accepted by PVUSA and the number of hours per month.

Figure 4-4 details 1991 monthly capacity factors for the six completed arrays. The same wide seasonal swing in performance as was shown in Figure 4-1 for energy output is exhibited.

\section{SYSTEM AVAILABIUTY}

System availability is defined by PVUSA as the percentage of daytime hours during which a system's ac power output exceeds $0.1 \mathrm{~kW}$. System-based availabilities are affected by the array orientation and system operating characteristics and reliability. Availability is also affected by poor weather, because at very low irradiance during cloudy daytime hours, power output may drop below the $0.1 \mathrm{~kW}$ threshold.

Figure 4-5 charts system availabilities for the six arrays during 1990 and 1991. (No data are available for 1989.) The average availability of these systems over the reporting period has been about 80 percent, and has typically ranged between 60 and 90 percent. A notable exception is the Sovonics array at Davis, due to the junction box failure noted earlier.

System availability calculations are sensitive to the amount of time during which array power is not high enough to overcome the PCU's internal load (about $0.4 \mathrm{~kW}$ for the EMT DECC PCU). During the hours near sunrise and sunset, the irradiance and PCU efficiency are often too low to produce net power output. Also, arrays with higher ratings can be expected to exceed the PCU's minimum requirements at lower irradiance levels than arrays with low ratings. However, the amount of unused potential energy during the sunrise and sunset hours 


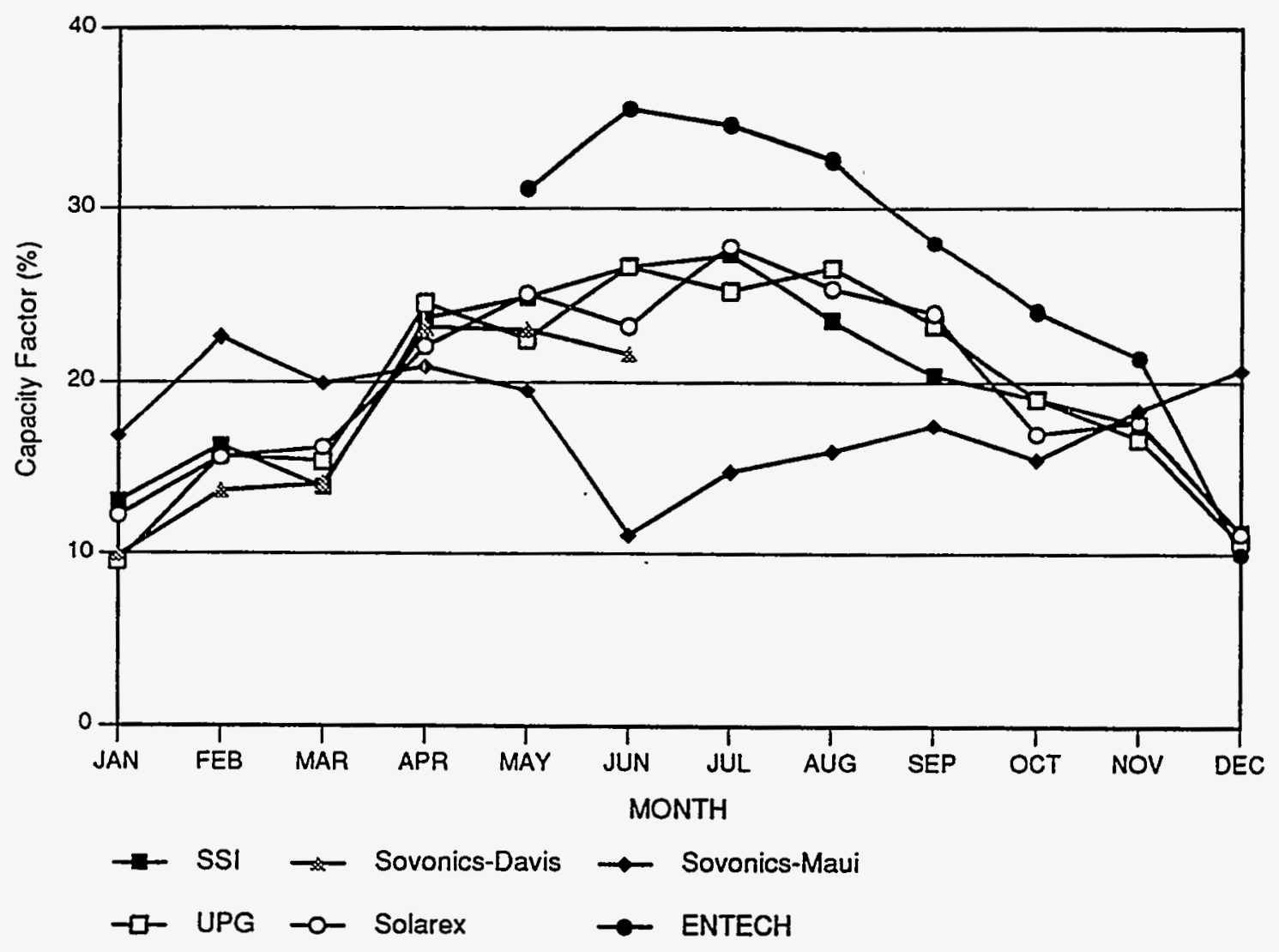

Capacity factor $=\frac{\text { monthly ac energy }(\mathrm{kWh})}{\text { ac rating }(\mathrm{kW}) \times \text { hours per month }}$

Figure 4-4

1991 PVUSA Capacity Factors

Davis and Maui Sites 


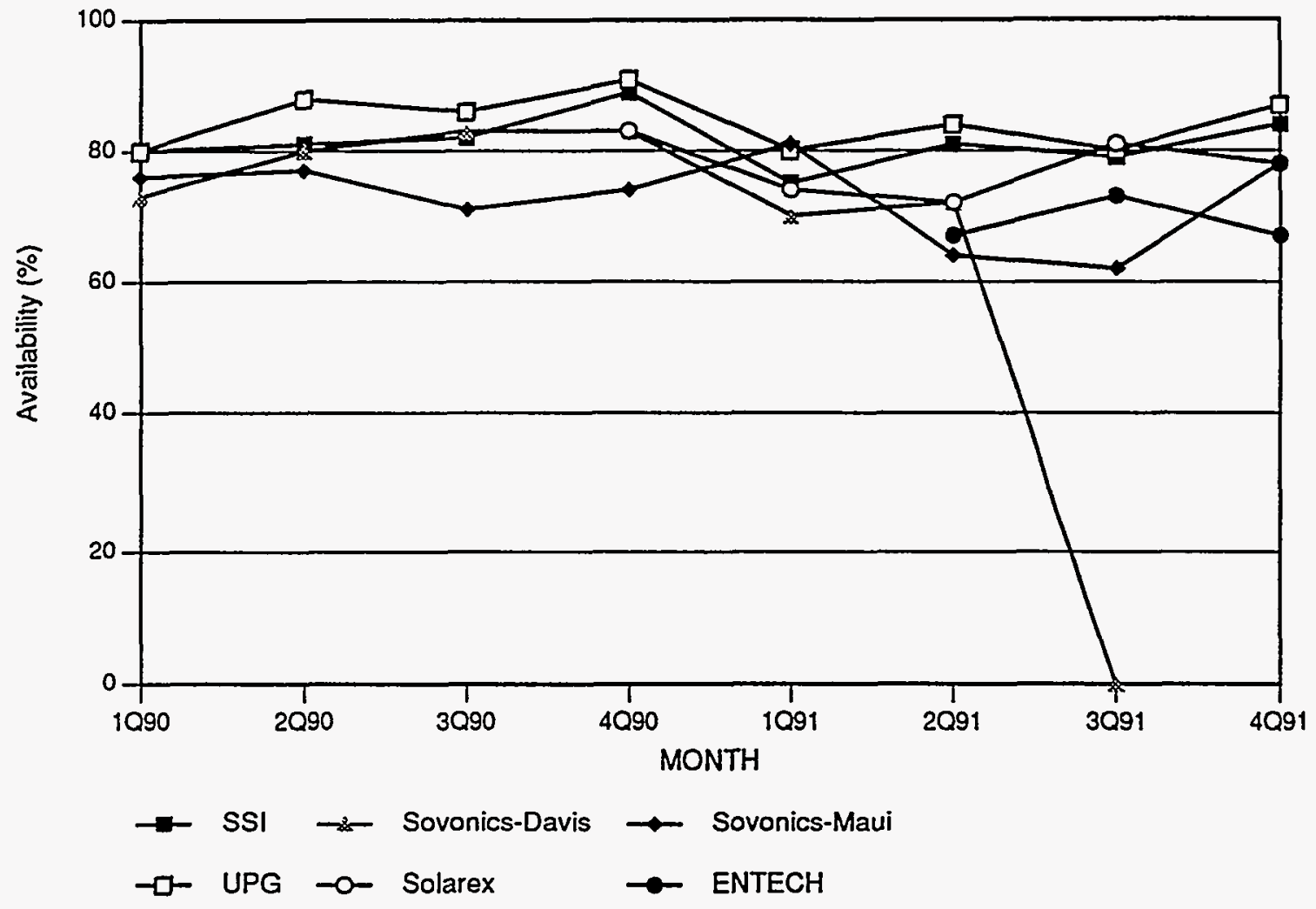

Percent of daytime hours with ac power $>0.1 \mathrm{~kW}$

Figure 4-5

PVUSA EMT-1 Availabilities

is small; typically, less than 2 percent of the total daily insolation. Therefore, availability as defined here is a conservative number.

\section{OPERATION AND MAINTENANCE}

One of PVUSA's objectives is to assess the operation and maintenance (O\&M) requirements of PV systems within an electric utility setting. A summary of the major 1991 O\&M activities for the six EMT-1 arrays and the BOS components appears below. A complete list of preventive, failure-related, and research O\&M activities is shown in Appendix $C$. 


\section{SSI EMT-1}

- One of 400 modules was replaced due to damage by a stray bullet from a nearby shooting range.

- A source circuit fuse and thermocouple failed.

\section{Sovonics Davis}

- Seven of 1200 modules were replaced. One failure was due to shorted grid lines; six had evidence of front surface delamination.

- The array was non-operational during the second half of 1991 due to a dc source circuit combiner junction box fire, which originated from protection devices (movistors). The cause of the fire is unknown. A new box was fabricated and will be installed in mid-1992.

- An underground cable ground fault was found; the cable will be replaced in mid-1992.

\section{Sovonics Maui}

- Eleven of 1200 modules were replaced. All module failures were due to melted or open-circuited junction boxes. Module failures were typically detected by large voltage imbalances, which were eliminated upon module replacement.

UPG

- One of 4992 modules was replaced in 1991 due to shattered back cover glass of unknown cause. (The module was functioning.)

\section{Solarex}

- None of 336 modules failed in 1991.

- One circuit junction box connection failed and was repaired.

\section{ENTECH}

- None of 60 modules failed in 1991.

- Tracker roll motor fuses were replaced twice due to mechanical interference and subsequent motor overcurrent.

- The tracker controller failed several times and was redesigned and replaced. 
- The dc stow battery, which is used to stow the array in a minimum wind-load position, failed due to overcharge.

- One dc cable clamp broke loose.

\section{EMT PCUs}

- Thirty-two manual restarts were required in 1991 for the PCU connected to the Sovonics Maui array. Twenty-six manual restarts were required in 1991 for the PCU on the Sovonics Davis array due to synchronization, sequencing, and door interlock errors.

- Other problems included: six ac power transducer fuse failures, two push-on terminal failures, two transducer wiring errors, one maximum power-tracking circuit failure, and one dc power transducer circuit failure.

- The DECC PCU connected to the ENTECH array required sequencing and synchronization adjustments by the manufacturer before start-up could proceed. (The other PCUs required similar adjustments in prior years.) 
Section 5

SPECIAL TESTS AND SITE SAFETY

This section describes 1991 islanding and power quality tests. It also discusses safety issues relevant to the PVUSA sites and 1991 safety efforts.

For more information on power quality, performance, and safety test results prior to 1991, see the $1989-1990$ PVUSA Progress Report.

\section{ISLANDING}

Islanding, or run-on, is of great interest as a safety issue because it can affect the safety of utility line crews performing repair or maintenance work. The purpose of the tests performed was to see if islanding could occur and to characterize it for the inverters installed at PVUSA, both independently and when operating in parallel.

Testing was based on ANSI/IEEE standard 1035-1989, "Test Procedure for Utility Interconnected Static Power Converters," which, among other things, provides a procedure to determine disconnect times for isolated generation/load combinations and multiple PCUs. The test utilized an adjustable load bank consisting of resistive loads in 5-kW steps. Inductive and capacitive loads were not available except for the cooling fan on the load bank. Results appear in Figures 5-1 through 5-4.

Islanding tests were performed in August on the PCUs connected to the SSI and UPG arrays; other EMT PCUs were either not available or undergoing data collection at the time. These two EMT-1 systems, as do all EMT systems, have identical DECC Helionetics inverters. The $25-\mathrm{kW}$ dc inverter was designed with a very wide operating voltage window--240 to 540 volts dc--to allow suppliers flexibility in their PV array designs.

The voltage source-type inverters are self-commutated using high-voltage transistors. Transistor drive signals are generated from a voltage-controlled oscillator, which is directly referenced to the ac grid. The unit consists of two bridges that are pulse-width modulated with the outputs combined by a technique referred to as stepped-wave summing. The inverters operate at near constant unity power factor.

While the PVUSA specification required that the inverter sense loss of utility grid and initiate separation to prevent islanding, DECC employs frequency and voltage sensing to determine presence and acceptability of the grid. (Newer methods include forced frequency variation, impedance change detection, and third harmonic sensing.) Consequently, the potential for islanding under favorable conditions does exist. 
The first sequence involved a single inverter (SSI array). Maximum output was about $15 \mathrm{~kW}$. Data points were taken for load-to-generation ratios from 0.8 to over 2.0. The PCU was left in peak power tracking mode. PCU power factor (0.98) remained constant when power was above about 50 percent, as was the case where runon was achieved. Figure 5-1 shows the PCU had a definite tendency to run on (possibly indefinitely) at load ratios of 1.1 to 1.2. One test had a run-on time of over 11 minutes.

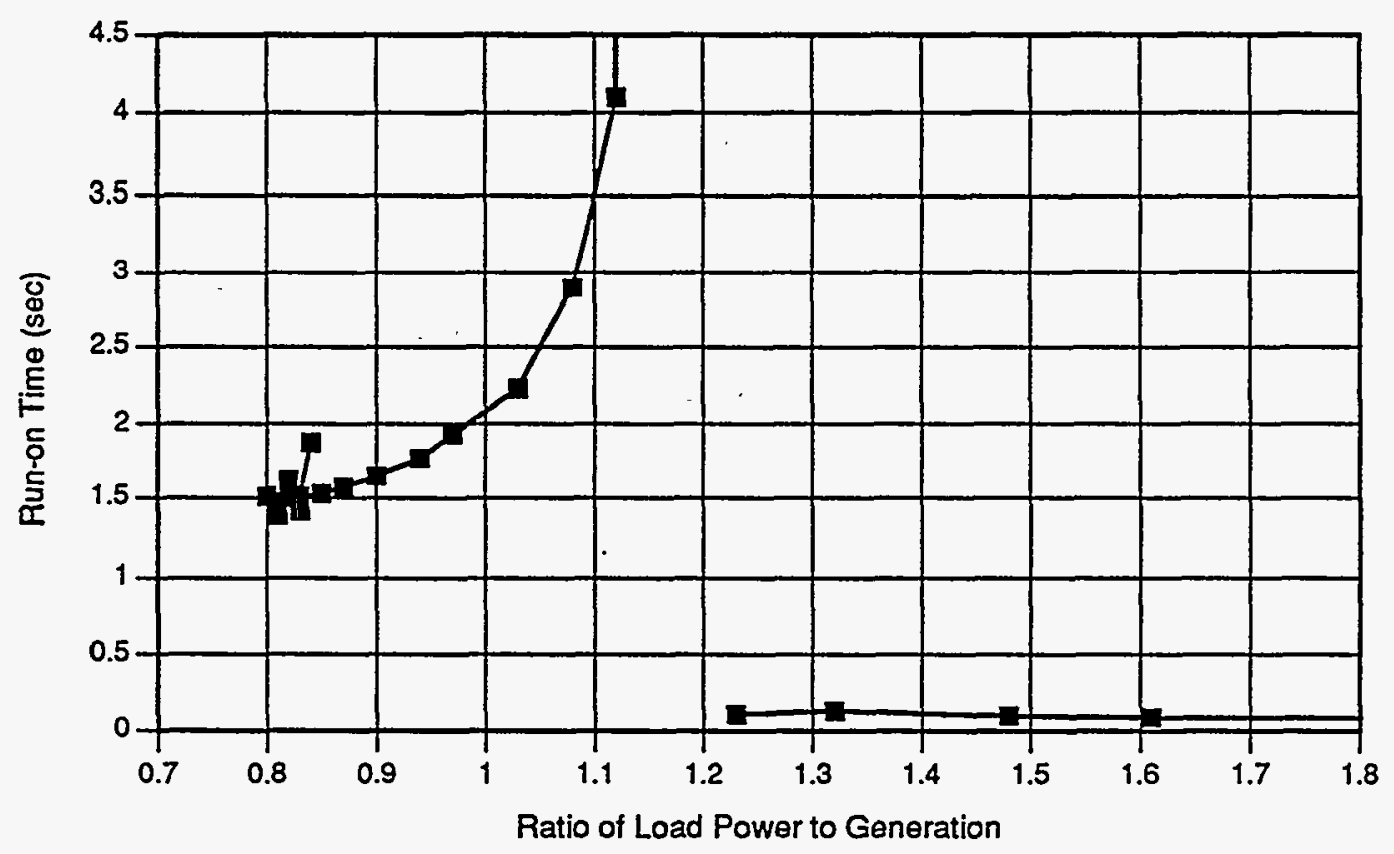

Figure 5-1

PVUSA EMT-1 DECC Inverter Island Test SSI Array - Load Fan Connected to Island Bus Inverter Peak Power Tracking 
The second test was with two PCL's (SSI and UPG), operated in parallel. Similar results were obtained. Here, run-on of more than 5 minutes occurred, until intentional shading of one array caused enough imbalance to trip the PCU (see Figure 5-2).

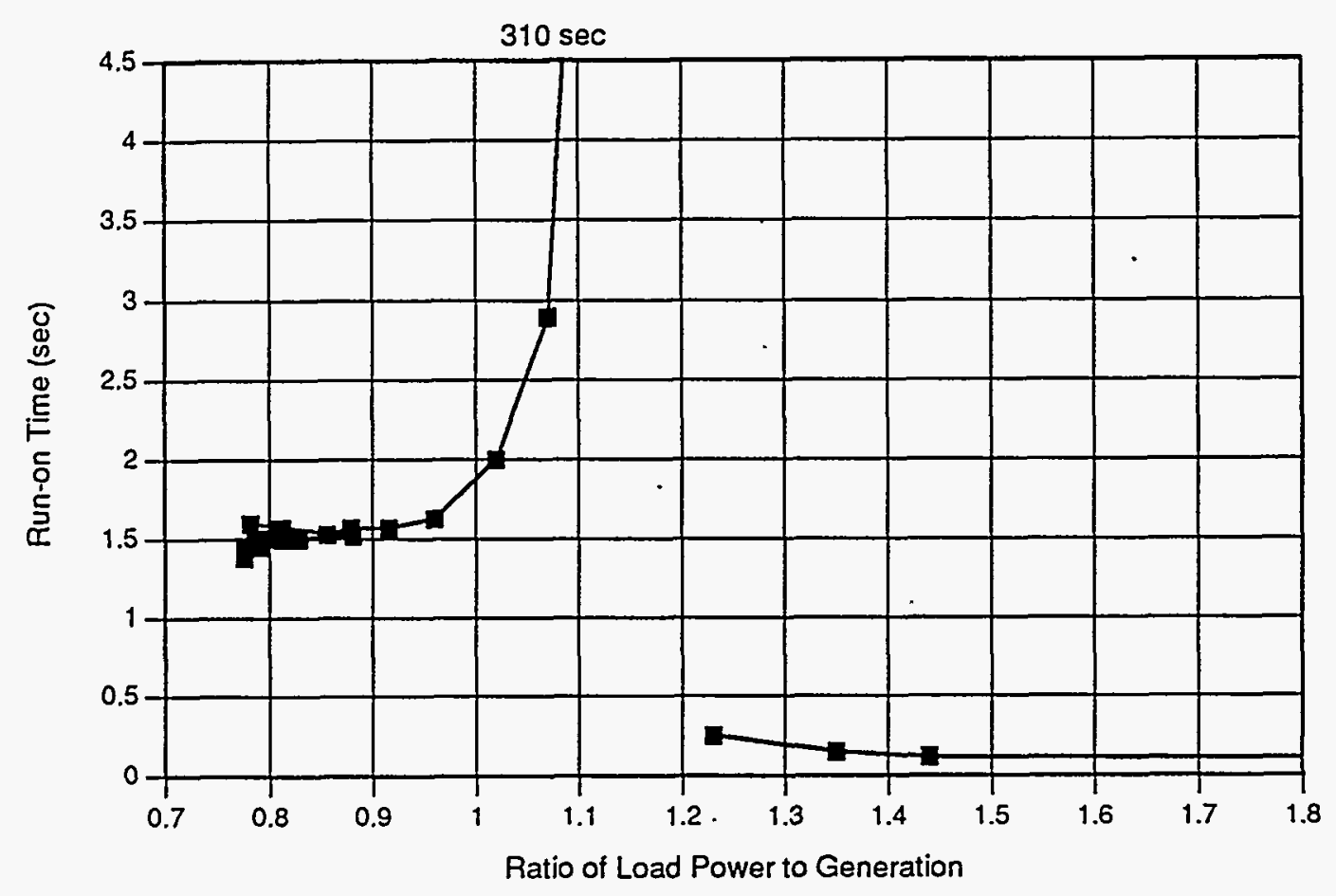

Figure 5-2

PVUSA EMT-1 DECC Inverter Island Test

SSI and UPG Arrays - Load Fan Connected to Island Bus Inverter Peak Power Tracking

A plot of the voltages and currents (see Figure 5-3) shows how balance was achieved to create islanding when the load and generation were initially unequal. The operation point travelled down the knee of the array's current-voltage curve, increasing voltage and reducing current. The frequency on the ac side remained very steady, deviating less than $1 / 2 \mathrm{~Hz}$ while islanding. 


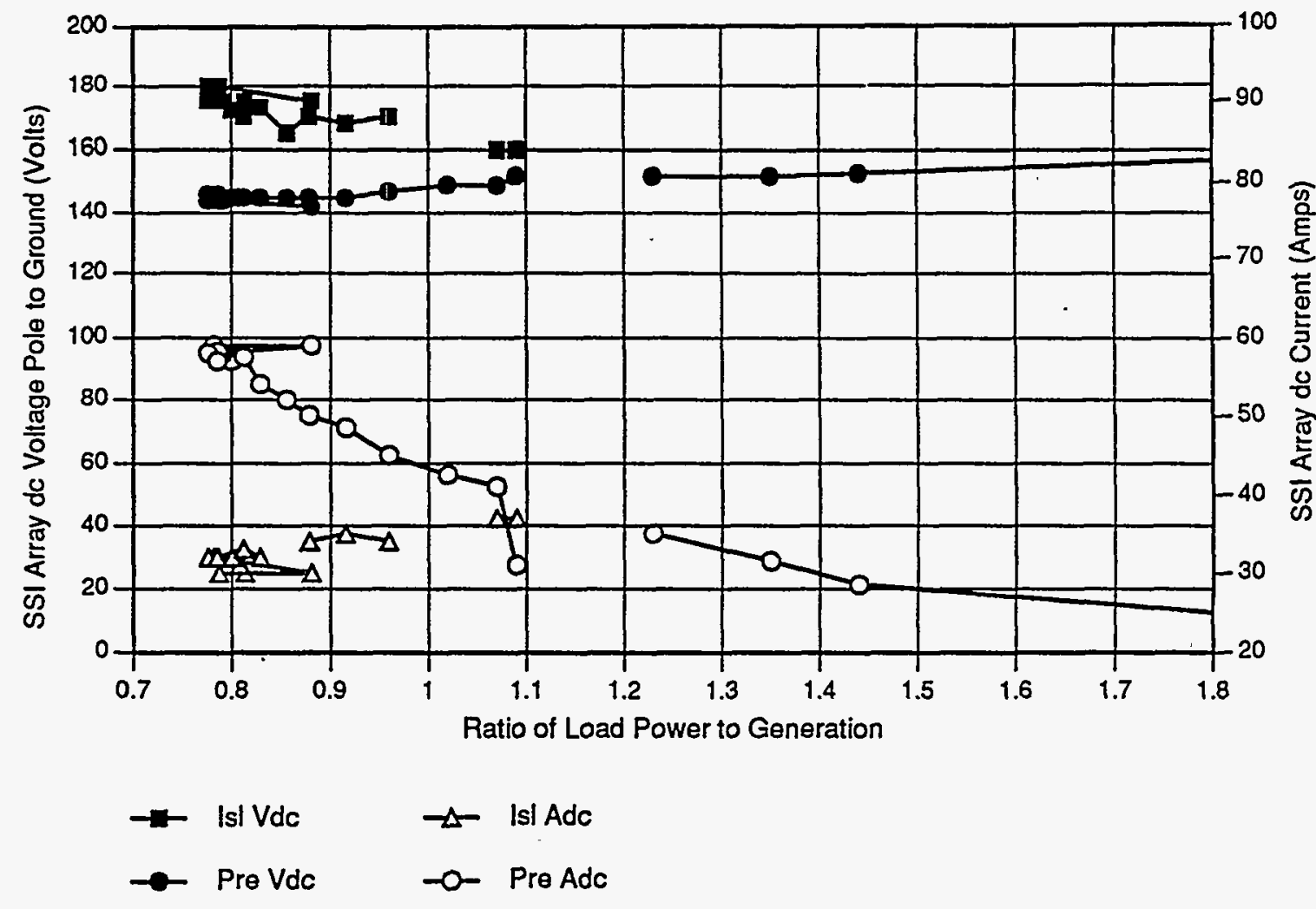

Figure 5-3

PVUSA EMT-1 DECC Inverter Island Test SSI and UPG Arrays Connected to Grid

Of interest is how the PCUs eventually tripped after islanding. As stated above, assuming no fault condition and relatively balanced three phase loads, the only sensing on the ac side of the inverter that can detect islanding is the voltage and frequency monitoring circuits. Although the frequency deviated only $1 / 2 \mathrm{~Hz}$ while islanding, the system would eventually become unstable and frequency would start swinging. The frequency swings would rapidly increase until the frequency relay would pick them up and trip the unit.

The tests show that islanding can happen under certain conditions. This possibility must be evaluated before installing a PCU by comparing general line and load configurations to the expected PV system output. The actuality of islanding and the problems it presents reinforces the need to develop and integrate some of the 
new anti-islanding concepts presented by the Central Research Institute of Electric Power Industry (Japan), Arizona State University, and others.

\section{POWER QUALTY TESTS}

A characterization was performed on one of the DECC Helionetics EMT PCUs to determine the correlation of power factor to PCU operating voltage. Figure 5-4 shows the power factor is constant over a wide operating range, decaying on the low end due to low dc voltage (high VAR draw) and on the high end due to low power.

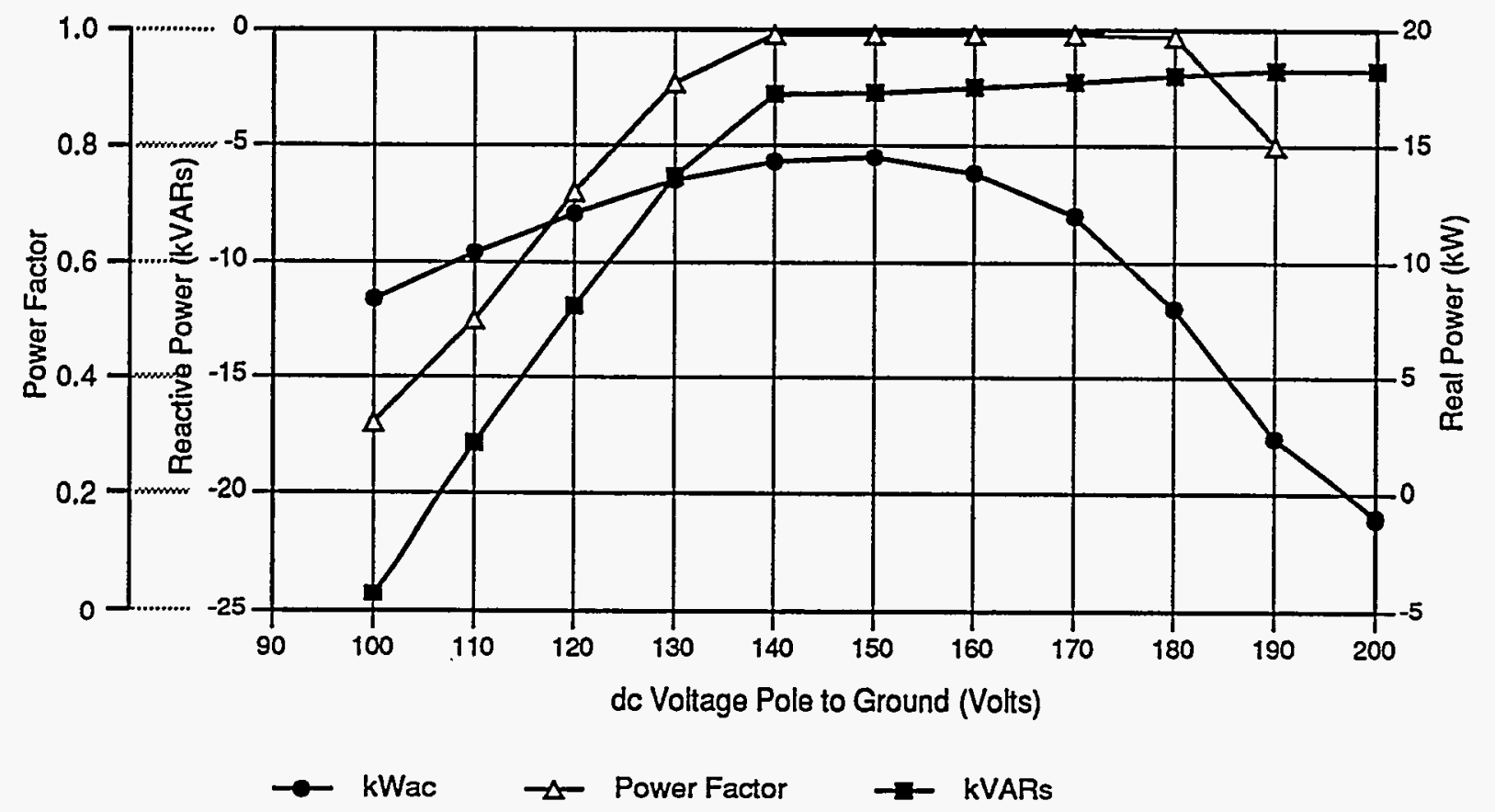

Figure 5-4

PVUSA EMT-1 DECC Inverter Characterization SSI Array Connected to Grid 


\section{SITE SAFETY}

On August 7, an SSI field representative received an electrical shock when he accidentally contacted a highvoltage do terminal while making measurements on the Bluepoint inverter with a hand-held multimeter. The SSI employee is recovering. In response, representatives from the DOE, Brookhaven National Laboratories, the CEC, and Reynolds Electric conducted a safety review at the Davis site and PG\&E's San Ramon office in December. Topics included overall site safety responsibility, project organization, and evaluation of the site safety program. A draft report of the group's findings and recommendations was being reviewed by PG\&E and Bechtel at year's end. Significant effort continues to ensure an enhanced safety program at the PVUSA Davis site. The PVUSA safety program provides a foundation for developing safety programs at other PV installations within the utility sector. 


\section{Section 6}

\section{KEY FINDINGS}

\section{PROCUREMENT AND CONSTRUCTION}

The most signilicant factors to date affecting schedule performance have been manufacturing delays, module qualification difficulties, and PCU start-up problems. Most suppliers have underestimated the time and effort required to advance their technologies or production facilities to the point where the proposed module or system can be manufactured and installed. Many PV system suppliers also lack experience in system design and installation, or lack facilities to perform qualification tests. In addition, some schedules for module manufacture and delivery were delayed by the inability of the modules to pass PVUSA's rigorous qualification tests. As a result, completion of the EMT-2 and US-1 systems, originally targeted for late 1990, is expected to be delayed until mid-1993 and late 1992, respectively. (All EMT-2 and US-1 completion dates in this report are forecasted by PVUSA as of June 1992.) Lessons learned from the Phase 1 US procurement process were incorporated into the Phase 2 RFP. The improved RFP, used to procure Phase 2 US systems, is a high-quality document that will continue to evolve with future PVUSA procurements to promote low-cost, utility-grade PV installations.

Fundamental differences in design configuration, material selection and shapes, ease of construction, economy of scale, and labor efficiency contributed to lower foundation and support structure costs for APS US-1.

Based on PVUSA observations to date, the potential to reduce PV system costs is significant and poses a challenge to the PV industry. In addition to installing the most efficient, cost-effective modules with the least expensive BOS, approaches to reduce PV system costs include incorporating standardized materials whenever possible in the foundation and structure design; minimizing fabrication, alignment, and installation labor requirements for one-axis tracking designs; and developing realistic and optimized delivery schedules for system components.

\section{ENGINEERING}

Vendors have experienced problems when incorporating unproven components into PV systems. For example, the scaling up of the Bluepoint inverters for the SSI US-1 system has been a challenge, as the inverters are suffering from ongoing start-up problems, voltage imbalances, and ground faults. IPC also found it difficult to meet their proposed schedule. In this case, Mobil Solar's new modules with innovative connector and wiring harnesses were found to have catastrophic wiring design and materials compatibility problems. 


\section{PERFORMANCE}

EMT-1 vendors have tended to be optimistic regarding expected array efficiencies: field performance has been lower than vendors' estimates, SSI being the sole exception. In 1991, the ENTECH array was rated at $16.5 \mathrm{~kW}$, about 23 percent below the vendors' expected rating of $21.5 \mathrm{~kW}$.

Consistent with data reported in the 1989-1990 PVUSA Progress Report, annual capacity factors for fixed-tilt arrays operating at Davis continue to be approximately 20 percent. This is slightly lower than the maximum expected capacity factor of 23 percent for fixed-tilt angle systems based on long-term average weather data for Davis. This difference is in part due to the lower than expected availability of many systems. Capacity factors were over 60 percent during PG\&E's summer on-peak hours (weekdays, noon to 6:00 p.m.).

EMT-1 system availability averaged about 80 percent during 1990-1991. Winter availabilities for the Davis systems have typically been lower than during other seasons, because the Davis site tends to have long periods of heavily overcast skies or rain. The Maui site availability has been influenced more by grid disturbances, as indicated by the large number of PCU trips during the year.

\section{OPERATION AND MAINTENANCE}

Key operation and maintenance findings specific to each EMT-1 array are summarized below:

\section{SSI and UPG}

Both arrays performed reliably in 1991.

\section{Sovonics Davis and Maui}

As a result of the array source circuit combiner junction box fire, the Davis array was out of commission for the second half of 1991. The Davis junction box design was modified to limit damage to neighboring components in the event of movistor failure or fire. Module delamination problems continued to appear at Davis; although Sovonics changed their laminating process for the modules used in the Maui array, minor delaminations at Maui were observed in 1991. The Maui array continues to be more efficient than the Davis array, the difference being attributed to module design improvements and site-specific weather characteristics.

\section{Solarex}

A terminal block meltdown and opening of a source circuit were identified and repaired. 


\section{ENTECH}

Interference between the modules and the roll rod brackets caused the tracker roll motor to overload and blow several fuses. The bracket was adjusted to eliminate mechanical interference. The tracker controller was less reliable than expected, required service on several occasions, and had to be replaced once. The manufacturer is working to improve the controller circuitry.

\section{SPECIAL TESTS}

The commonly held belief that inverters can island under certain conditions was validated for the EMT DECC inverters. Because islanding is a real safety concern, particularly for larger inverters, this finding underscores the need for further development and incorporation of active design features that will detect and prevent inverter islanding on a utility grid.

\section{TECHNOLOGY TRANSFER}

PVUSA operational and maintenance experience for the EMTs is being considered by manufacturers as nextgeneration PV technologies appear. EMT-1 PV manufacturers are using the lessons learned at PVUSA. EMT-1 manufacturers are actively optimizing next-generation module designs based on their EMT-1 manufacturing experiences and on demonstrated performance and reliability results at PVUSA. At least one EMT-1 manufacturer appears to have terminated further EMT-1 technology development to pursue alternative, more promising PV technologies.

Domestic and international interest in the PVUSA project is strong. The Davis facility hosted tours for more than 700 visitors from approximately two dozen countries, and PVUSA project team members were invited to participate at a number of technical conferences. Lessons learned at PVUSA are also being applied to standards development work at IEEE and IEC. 


\section{CONCLUSIONS AND FUTURE WORK}

\section{CONCLUSIONS}

1. Federal and state agencies, national laboratories, PV manufacturers, and the utility industry continue to work together effectively to plan and carry out a large-scale PV demonstration program. Participating utilities are learning to specify and operate PV systems, and the PV industry is learning how to supply systems to utility standards.

2. Schedule slippages for both the EMT and US systems continue. Vendors find it difficult to meet their proposed schedule and performance requirements while tackling technical and financial challenges. Also, the stringent but necessary requirements of PVUSA qualification tests, which play a key role in ensuring module and system reliability, have contributed significantly to schedule revisions. Schedule delays raise concerns about the readiness of the PV industry to deliver utility-scale, utility-grade systems when needed.

3. The improved US RFP, modified based on PVUSA lessons learned from Phase 1 procurements, is a highquality document that will continue to evolve with future PVUSA procurements to promote low-cost, utilitygrade PV installations.

4. For the EMT arrays installed to date, the manufacturers' expected power ratings are typically higher than actual power ratings. In general, the arrays are stable and reliable.

5. The ability of EMT-1 PV manufacturers to supply lower-cost, more-efficient, utility-grade PV modules is enhanced by EMT-1 manufacturing experiences and lessons learned from the fielded arrays at PVUSA.

\section{FUTURE WORK}

1. PVUSA will continue to closely monitor and assess PV vendor performance to ascertain strengths, weaknesses, and areas of improvement necessary to successfully support utility demand for electric generation sources.

2. While PVUSA recognizes that pushing the development of previously untried PV systems carries with it inherent technical and scheduling challenges, there will be a concerted effort to aggressively work with system suppliers to meet schedules for future installations. Changes to the procurement process initiated in 1991, requiring EMT-3 manufacturers to test $1 \mathrm{~kW}$ of their technology with supervision by the National 
Laboratories, are expected to provide more realistic manufacturer schedules by identifying potential technical problems earlier.

3. PVUSA will continue to participate in PV standards development committees. Participation is an important aspect of PVUSA's technology transfer program, and ensures that PV standards incorporate a utility perspective.

4. PVUSA will continue to monitor PV array and system performance; develop a Project Plan to optimize testing, data collection, analysis, and reporting; comprehensively assess BOS costs; develop and optimize procedures to capture maintenance requirements and costs; and establish a Safety and Health Action Plan to ensure the effectiveness of the safety program at the PVUSA Davis site. 
Appendix A

WEATHER DATA 


\section{WEATHER DATA}

Table A-1 compares 1989, 1990, and 1991 totals for several weather characteristics at the Davis site. Table A-2 compares 1990 and 1991 totals for the Maui site. Because of data logger input limitations, fewer quantities are measured at the Maui site. Detailed monthly weather and performance summaries for 1991 are included in Appendix $B$.

Figure A-1 shows the monthly insolation during 1991 at the Davis site for five orientations: global horizontal, global $30^{\circ}$ tilt, global normal, direct normal, and global north-south single-axis.

Relative to the highest annual quantity, global normal, the next best orientation was the global-single axis, which received 89 percent of the global normal insolation. Direct normal insolation was 74 percent of the global normal, global $30^{\circ}$. tilt insolation was 70 percent, and the global horizontal was 62 percent.

The global $30^{\circ}$ tilt insolation showed the smallest seasonal variation. Single-axis insolation had a wide seasonal variation. During the summer it received nearly as much insolation as the global normal, but in the winter, it approached the global horizontal insolation. The horizontal orientation received its highest insolation during the summer months, even surpassing the $30^{\circ}$ tilt, because the solar incidence angles are smaller on the horizontal surface during summer. During the winter the incidence angles are always high (at least $60^{\circ}$ ), the days are short (9.3 hours as opposed to 14.6 hours in the summer) and horizontal surfaces receive much less insolation.

Much of Davis' rainfall occurs during the winter months, and there are often prolonged periods with heavy fog. The amount of insolation on any orientation, especially direct normal, is reduced greatly during overcast periods.

1991 monthly POA insolation data for the Maui site is shown in Figure 4-2, along with the Maui site's monthly energy production. Although the annual insolation for the fixed $30^{\circ}$ tilt in Davis has been nearly the same as the annual insolation for the $22^{\circ}$ tilt or horizontal orientation in Maui, the seasonal variation in insolation (especially for the $22^{\circ}$ tilt) is smaller at Maui. Seasonal variations of day length are reduced as latitude approaches the equator. Additionally, site weather characteristics at Maui tend to be less seasonally dependent. For the Maui site in 1991, the month with the highest insolation was only 33 percent higher than the average monthly insolation over the past two years. The worst month was only 6 percent less than the two-year monthly average. At Davis, the best month in 1991 was 34 percent above the three-year average and the worst month was only 53 percent of the three-year average. 
Table A-1

PVUSA Davis Weather Summary

\begin{tabular}{||lccc||}
\hline & 1991 & 1990 & 1989 \\
\hline Insolation, $\mathrm{kWh} / \mathrm{m}^{2}$ & & & \\
$\quad$ Global horizontal (long-term=1838) & 1877 & 1890 & 1812 \\
Global $30^{\circ}$ tilt & 2123 & 2213 & 2104 \\
1-axis tracking (horz. $\mathrm{N}-\mathrm{S}$ axis) & 2707 & $\mathrm{n} / \mathrm{a}$ & $\mathrm{n} / \mathrm{a}$ \\
Global normal & 3044 & 3185 & 2982 \\
Direct normal $^{\circ}$ & 2260 & 2509 & 2189 \\
Average $\mathrm{T}_{\text {ambient' }}{ }^{\circ} \mathrm{C}$ (long-term $\left.=15^{\circ} \mathrm{C}\right)$ & 15.6 & 15.7 & 14.9 \\
Minimum, $\mathrm{T}_{\text {ambient' }}{ }^{\circ} \mathrm{C}$ & -6.0 & -9.7 & -6.4 \\
Maximum $\mathrm{T}_{\text {ambient' }}{ }^{\circ} \mathrm{C}$ & 43.8 & 42.7 & 43.7 \\
Average wind speed, $\mathrm{m} / \mathrm{s}$ & 3.2 & 3.2 & 2.9 \\
Maximum wind speed, $\mathrm{m} / \mathrm{s}$ & 14.1 & 13.7 & 17.5 \\
Rainfall, inches & 15 & 13 & 13 \\
\hline \hline
\end{tabular}

Table A-2

PVUSA Maui Weather Summary

\begin{tabular}{||ccc||}
\hline & 1991 & 1990 \\
\hline Insolation, $\mathrm{kWh} / \mathrm{m}^{2}$ & & \\
Global horizontal (long-term average $\mathrm{N} / \mathrm{a})$ & 2075 & 2122 \\
Global $22^{\circ}$ tilt & 2158 & 2078 \\
Average $\mathrm{T}_{\text {ambient' }}{ }^{\circ} \mathrm{C}$ & 28.0 & 28.0 \\
Minimum $\mathrm{T}_{\text {ambient' }}{ }^{\circ} \mathrm{C}$ & 17.0 & 15.8 \\
Maximum $\mathrm{T}_{\text {ambient' }}{ }^{\circ} \mathrm{C}$ & 42.4 & 44.0 \\
Average wind speed, $\mathrm{m} / \mathrm{s}$ & 3.5 & 3.0 \\
Maximum wind speed, $\mathrm{m} / \mathrm{s}$ & 14.0 & 14.7 \\
\hline
\end{tabular}




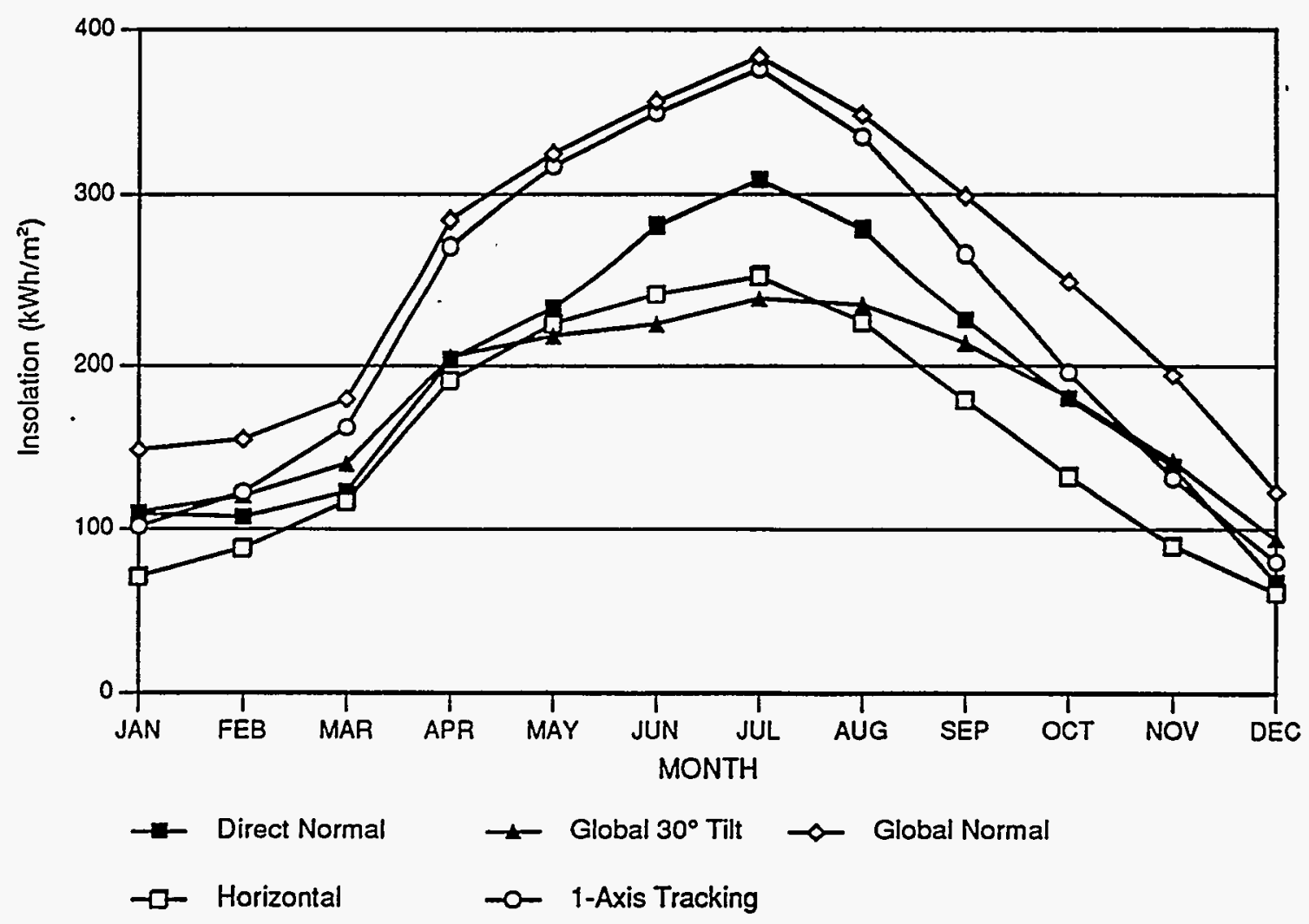

Figure A-1

1991 PVUSA Davis Insolation

The average wind speeds are similar for the Davis and Maui sites. The average temperatures have been more than $23^{\circ} \mathrm{F}$ higher in Maui than in Davis, although the maximum temperatures have been similar. 
Appendix B

DETAILED MONTHLY WEATHER AND PERFORMANCE SUMMARIES 


\section{DETAILED MONTHLY WEATHER AND PERFORMANCE SUMMARIES}

Tables B-1 through B-3 contain detailed month-by-month data on solar resource, site weather, and system performance for the PVUSA Davis, California site. Tables B-4 through B-6 contain similar data for the PVUSA Maui, Hawaii site. Fewer quantities are measured at the Maui site.

Array and system efficiencies are based on the module area times the number of modules in the system. System availability is defined by PVUSA as the percentage of daytime hours where the system ac power is greater than $0.1 \mathrm{~kW}$.

Filtered and unfiltered solar resource data are listed for the Davis site. Filtered measurements include wavelengths of solar radiation between 780 nanometers $(\mathrm{nm})$ and $3000 \mathrm{~nm}$. Unfiltered measurements are based on wavelengths between $300 \mathrm{~nm}$ and $3000 \mathrm{~nm}$. 
Table B-1

1991 PVUSA Davis Solar Resource Data

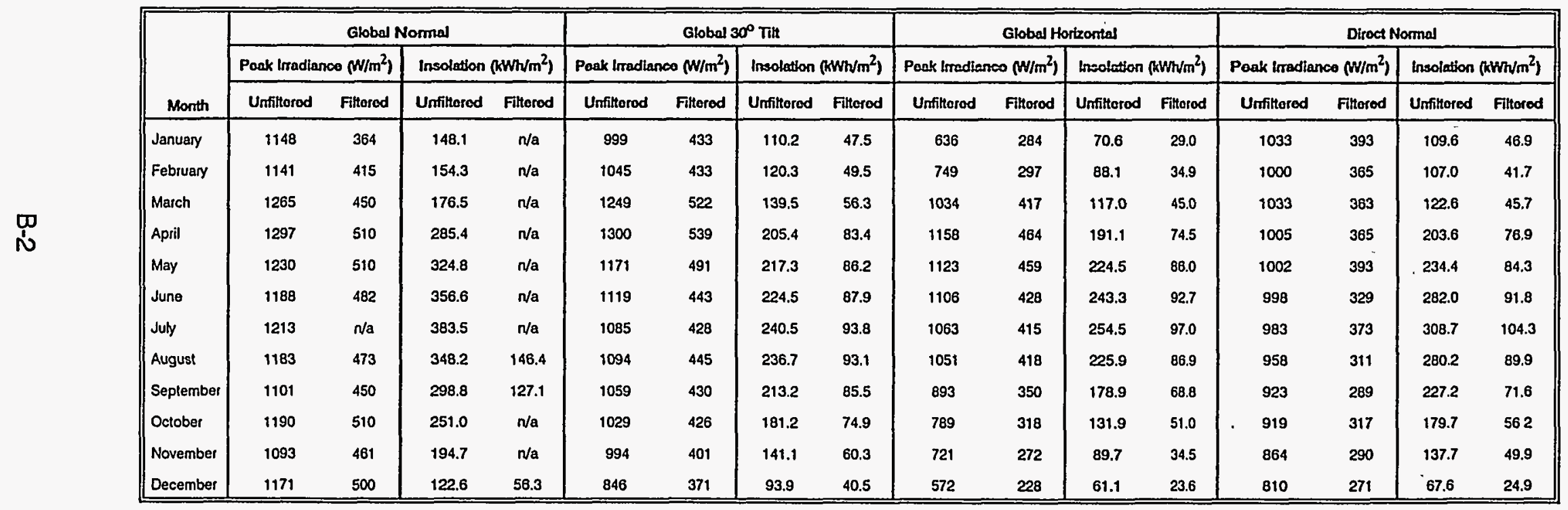


Table B-2

1991 PVUSA Davis Weather Data

\begin{tabular}{||l|ccc|ccc|cc||}
\hline \multirow{4}{*}{ Month } & \multicolumn{2}{|c|}{$\begin{array}{c}\text { Ambient Temperature } \\
\left.\text { ( }{ }^{\circ} \mathrm{C}\right)\end{array}$} & \multicolumn{3}{c|}{$\begin{array}{c}\text { Wind Speed } \\
\text { (m/s) }\end{array}$} & \multicolumn{2}{c||}{ Precipitation } \\
\cline { 2 - 9 } & Min. & Avg. & Max. & Min. & Avg. & Max. & $\begin{array}{c}\text { Total } \\
\text { (in/month) }\end{array}$ & $\begin{array}{c}\text { Max } \\
\text { (in/day) }\end{array}$ \\
\hline January & -6.0 & 6.9 & 21.9 & 0.0 & 2.7 & 13.7 & 0.04 & 0.04 \\
February & -2.0 & 11.7 & 25.6 & 0.1 & 2.6 & 10.8 & 3.1 & 1.15 \\
March & -0.2 & 9.8 & 22.8 & 0.0 & 4.2 & 13.5 & 3.72 & 0.83 \\
April & 2.2 & 13.9 & 28.7 & 0.0 & 3.9 & 13.4 & 0.71 & 0.71 \\
May & 3.0 & 17.0 & 34.8 & 0.0 & 3.6 & 12.1 & 0.06 & 0.06 \\
June & 7.0 & 17.0 & 37.0 & 0.0 & 3.6 & 11.9 & 0.3 & 0.21 \\
July & 11.4 & 24.1 & 43.8 & 0.0 & 2.8 & 8.6 & 0.05 & 0.05 \\
August & 8.7 & 21.6 & 36.3 & 0.0 & 3.0 & 9.0 & 0.07 & 0.07 \\
September & 9.9 & 22.6 & 40.0 & 0.0 & 2.5 & 9.0 & 0.0 & 0.0 \\
October & 1.5 & 19.4 & 38.2 & 0.0 & 3.2 & 12.1 & 0.62 & 0.38 \\
November & -1.8 & 12.2 & 26.1 & 0.0 & 3.3 & 14.1 & 0.3 & 0.14 \\
December & -3.5 & 6.7 & 17.9 & 0.0 & 2.8 & 12.6 & 2.17 & 0.73 \\
\hline Annual & -6.0 & 15.2 & 43.8 & 0.0 & 3.2 & 14.1 & 0.92 & 1.15 \\
\hline
\end{tabular}


Table B-3

1991 PVUSA Davis Performance Data

\begin{tabular}{|c|c|c|c|c|c|c|c|c|c|}
\hline Month & System & $\begin{array}{c}\text { T Mod. } \\
\text { Wt. Avg. } \\
\left.\rho^{\circ} \mathrm{C}\right)\end{array}$ & $\begin{array}{c}\text { POA } \\
\text { Insol. } \\
\left(\mathrm{kWh} / \mathrm{m}^{2}\right)\end{array}$ & $\begin{array}{c}\text { de } \\
\text { Energy } \\
\text { (kWh) }\end{array}$ & $\begin{array}{l}d c \\
\text { Eff. } \\
(\%)\end{array}$ & $\begin{array}{c}\text { Max de } \\
\text { Power } \\
\text { (kW) }\end{array}$ & $\begin{array}{c}\text { ac } \\
\text { Energy } \\
\text { (kWh) }\end{array}$ & $\begin{array}{c}\text { Max ac } \\
\text { Power } \\
\text { (kW) }\end{array}$ & $\begin{array}{c}\text { System } \\
\text { Avail. } \\
\text { (\%) }\end{array}$ \\
\hline \multirow[t]{4}{*}{ January } & SSI & 27.5 & 105.4 & 2005 & 11.27 & 19.1 & 1751 & 17.9 & 78 \\
\hline & Sovonics & 27.3 & 105.0 & 1349 & 2.58 & 14.1 & 1171 & 12.9 & 66 \\
\hline & UPG & 28.6 & 83.9 & 1160 & 2.90 & 13.2 & 1067 & 12.7 & 71 \\
\hline & Solarex & 25.8 & 104.2 & 1573 & 8.31 & 15.4 & 1368 & 14.7 & 71 \\
\hline \multirow[t]{4}{*}{ February } & SSI & 33.0 & 118.9 & 2228 & 11.1 & 18.9 & 1960 & 17.6 & 84 \\
\hline & Sovonics & 32.5 & 119.7 & 1671 & 2.81 & 15.2 & 1448 & 13.8 & 76 \\
\hline & UPG & 35.3 & 118.7 & 1698 & 3.0 & 14.0 & 1578 & 13.4 & 88 \\
\hline & Solarex & 31.1 & 118.0 & 1793 & 8.37 & 15.3 & 1573 & 14.5 & 79 \\
\hline \multirow[t]{4}{*}{ March } & SSI & 29.1 & 112.9 & 2122 & 11.13 & 22.6 & 1855 & 21.2 & 66 \\
\hline & Sovonics & 29.9 & 141.2 & 1978 & 2.82 & 17.8 & 1725 & 16.2 & 68 \\
\hline & UPG & 30.9 & 131.2 & 1856 & 2.97 & 16.4 & 1718 & 15.8 & 80 \\
\hline & Solarex & 28.5 & 135.8 & 2121 & 8.60 & 19.1 & 1867 & 18.3 & 72 \\
\hline \multirow[t]{5}{*}{ April } & SSI & 36.2 & 194.0 & 3420 & 10.44 & 23.4 & 3057 & 22.0 & 82 \\
\hline & Sovonics & 35.0 & 201.4 & 2987 & 2.98 & 18.6 & 2628 & 16.9 & 83 \\
\hline & UPG & 37.4 & 203.3 & 2816 & 2.91 & 16.7 & 2646 & 15.9 & 89 \\
\hline & Solarex & 34.5 & 170.8 & 2642 & 8.51 & 19.7 & 2391 & 18.9 & 71 \\
\hline & ENTECH ${ }^{*}$ & 43.0 & $\mathrm{n} / \mathrm{a}$ & 2974 & $n / a$ & 20.9 & 2735 & 19.4 & 63 \\
\hline \multirow[t]{5}{*}{ May } & SSI & 40.1 & 208.2 & 3695 & 10.51 & 20.6 & 3300 & 19.2 & 79 \\
\hline & Sovonics & 38.4 & 202.7 & 3085 & 3.06 & 17.3 & 2708 & 15.7 & 75 \\
\hline & UPG & 41.3 & 190.5 & 2682 & 2.95 & 15.5 & 2517 & 14.9 & 76 \\
\hline & Solarex & 38.0 & 203.7 & 3095 & 8.36 & 17.7 & 2792 & 16.9 & 76 \\
\hline & ENTECH ${ }^{*}$ & 47.7 & 152.5 & 3832 & 14.58 & 20.6 & 3614 & 20.4 & 67 \\
\hline \multirow[t]{5}{*}{ June } & SSI & 42.0 & 223.0 & 3841 & 10.20 & 18.9 & 3429 & 17.6 & 81 \\
\hline & Sovonics & 44.7 & 180.0 & 2801 & 3.13 & 16.4 & 2476 & 14.9 & 60 \\
\hline & UPG & 45.2 & 216.7 & 3055 & 2.96 & 16.1 & 2868 & 15.3 & 86 \\
\hline & Solarex & 43.3 & 217.9 & 3223 & 8.41 & 16.0 & 2511 & 15.2 & 68 \\
\hline & ENTECH ${ }^{*}$ & 53.5 & $n / a$ & 4226 & $n / a$ & 20.1 & 3970 & 19.1 & 72 \\
\hline
\end{tabular}

ENTECH experienced severe shading problems on instrumentation for direct normal irradiance in the early mornings and afternoons. Therefore, ENTECH efficiency is based only on data taken from 9 a.m. to 3 p.m. 
Table B-3

1991 PVUSA Davis Performance Data

(Cont'd)

\begin{tabular}{|c|c|c|c|c|c|c|c|c|c|}
\hline Month & System & $\begin{array}{c}\text { T Mod. } \\
\text { Wt Avg. } \\
\text { ('C) }\end{array}$ & $\begin{array}{c}\text { POA } \\
\text { Insol. } \\
\left(\mathrm{kWh} / \mathrm{m}^{2}\right)\end{array}$ & $\begin{array}{c}\text { dc } \\
\text { Energy } \\
\text { (kWh) }\end{array}$ & $\begin{array}{l}d c \\
\text { Eff. } \\
\text { (x) }\end{array}$ & $\begin{array}{c}\text { Max de } \\
\text { Power } \\
\text { (kW) }\end{array}$ & $\begin{array}{c}\text { ac } \\
\text { Energy } \\
(\mathrm{kWh})\end{array}$ & $\begin{array}{c}\text { Max ac } \\
\text { Power } \\
\text { (kW) }\end{array}$ & $\begin{array}{c}\text { System } \\
\text { Avail. } \\
\text { (\%) }\end{array}$ \\
\hline \multirow[t]{4}{*}{ July } & SSI & 49.3 & 240.5 & 4057 & 9.99 & 17.8 & 3636 & 16.6 & 82 \\
\hline & UPG & 52.0 & 201.0 & 2987 & 3.12 & 15.3 & 2809 & 14.6 & 75 \\
\hline & Solarex & 49.7 & 235.5 & 3418 & 7.99 & 15.1 & 3099 & 14.4 & 80 \\
\hline & ENTECH ${ }^{*}$ & 53.1 & 144.3 & 2718 & 10.93 & 18.6 & 2501 & 17.6 & 36 \\
\hline \multirow[t]{4}{*}{ August } & SSI & 45.7 & 209.2 & 3511 & 9.94 & 18.3 & 3142 & 17.0 & 76 \\
\hline & UPG & 48.4 & 210.7 & 3132 & 3.12 & 15.7 & 2951 & 15.1 & 83 \\
\hline & Solarex & 46.6 & 213.0 & 3109 & 8.04 & 15.5 & 2823 & 14.8 & 78 \\
\hline & ENTECH ${ }^{*}$ & 58.2 & 134.7 & 2589 & 11.14 & 18.7 & 2452 & 17.7 & 39 \\
\hline \multirow[t]{4}{*}{ September } & SSI & 46.2 & 183.8 & 2961 & 9.54 & 17.2 & 2647 & 16.0 & 78 \\
\hline & UPG & 50.5 & 183.3 & 2673 & 3.06 & 15.1 & 2526 & 14.5 & 82 \\
\hline & Solarex & 47.6 & 203.3 & 2858 & 7.74 & 14.7 & 2586 & 14.0 & 85 \\
\hline & ENTECH ${ }^{*}$ & 58.0 & 129.5 & 2360 & 10.56 & 16.4 & 2230 & 15.5 & 46 \\
\hline \multirow[t]{4}{*}{ October } & SSI & 40.5 & 167.5 & 2865 & 10.13 & 18.4 & 2557 & 17.2 & 83 \\
\hline & UPG & 46.0 & 160.5 & 2267 & 2.96 & 14.0 & 2135 & 13.5 & 86 \\
\hline & Solarex & 42.6 & 156.6 & 2127 & 7.48 & 15.3 & 1896 & 14.6 & 77 \\
\hline & ENTECH ${ }^{*}$ & 51.5 & 122.9 & 2159 & 10.19 & 19.3 & 2035 & 18.3 & 48 \\
\hline \multirow[t]{4}{*}{ November } & SSI & 31.6 & 136.6 & 2552 & 11.07 & 19.3 & 2278 & 18.1 & 87 \\
\hline & UPG & 34.5 & $n / a$ & 1918 & $n / a$ & 13.7 & 1801 & 13.1 & 90 \\
\hline & Solarex & 30.5 & 133.8 & 2125 & 8.74 & 16.5 & 1915 & 15.8 & 83 \\
\hline & ENTECH ${ }^{*}$ & 40.9 & 97.7 & 2054 & 12.20 & 18.0 & 1938 & 17.1 & 52 \\
\hline \multirow[t]{4}{*}{ December } & SSI & 24.3 & 93.2 & 1768 & 11.23 & 16.3 & 1521 & 15.1 & 80 \\
\hline & UPG & 26.5 & 90.9 & 1310 & 3.02 & 11.8 & 1207 & 11.3 & 86 \\
\hline & Solarex & 23.8 & 91.4 & 1455 & 8.76 & 13.7 & 1254 & 13.0 & 76 \\
\hline & ENTECH $^{*}$ & 36.1 & 50.3 & 1074 & 12.38 & 16.6 & 1009 & 15.6 & 32 \\
\hline
\end{tabular}

* ENTECH experienced severe shading problems on instrumentation for direct normal irradiance in the early mornings and afternoons. Therefore, ENTECH efficiency is based only on data taken from 9 a.m. to 3 p.m. 
Table B-4

1991 PVUSA Maui Solar Resource Data

\begin{tabular}{||l|cc|cc||}
\hline \multirow{3}{*}{ Month } & \multicolumn{2}{|c|}{ Global 220 Tilt } & \multicolumn{2}{c|}{ Global Horizontal } \\
\cline { 2 - 5 } & $\begin{array}{c}\text { Peak Irradiance } \\
\left(\mathbf{W} / \mathbf{m}^{2}\right)\end{array}$ & $\begin{array}{c}\text { Insolation } \\
\left(\mathbf{k W h} / \mathbf{m}^{2}\right)\end{array}$ & $\begin{array}{c}\text { Peak Irradiance } \\
\left(\mathbf{W} / \mathbf{m}^{2}\right)\end{array}$ & $\begin{array}{c}\text { Insolation } \\
\left(\mathbf{k W h} / \mathbf{m}^{2}\right)\end{array}$ \\
\hline January & 1196 & 184 & 998 & 145 \\
February & 1241 & 180 & 1101 & 151 \\
March & 1229 & 179 & 1152 & 169 \\
April & 1282 & 199 & 1259 & 204 \\
May & 1131 & 190 & 1212 & 213 \\
June & 1076 & 176 & 1181 & 206 \\
July & 1078 & 174 & 1159 & 198 \\
August & 1112 & 188 & 1153 & 199 \\
September & 1166 & 184 & 1196 & 178 \\
October & 1175 & 173 & 1044 & 153 \\
November & 1069 & 164 & 888 & 131 \\
December & 1043 & 167 & 830 & 129 \\
\hline
\end{tabular}

Table B-5

1991 PVUSA Maui Weather Data

\begin{tabular}{||l|rrr|rr||}
\hline \multirow{2}{*}{ Month } & \multicolumn{2}{|c|}{ Ambient Temperature $\left.{ }^{\circ} \mathrm{C}\right)$} & \multicolumn{3}{c|}{ Wind Speed $(\mathrm{m} / \mathrm{s})$} \\
\cline { 2 - 7 } & Min. & Avg. & Max & Avg. & Max \\
\hline January & 17.6 & 25.6 & 35.9 & 3.8 & 14.0 \\
February & 18.0 & 26.3 & 37.9 & 3.4 & 11.5 \\
March & 17.0 & 25.9 & 38.8 & 3.2 & 10.9 \\
April & 17.6 & 27.1 & 39.0 & 3.3 & 11.6 \\
May & 19.3 & 28.0 & 40.5 & 3.9 & 11.5 \\
June & 19.8 & 28.6 & 41.4 & 3.6 & 11.4 \\
July & 21.0 & 29.4 & 42.4 & 3.6 & 10.8 \\
August & 21.7 & 30.2 & 42.3 & 3.6 & 13.4 \\
September & 21.5 & 29.8 & 41.9 & 3.4 & 11.3 \\
October & 20.8 & 29.2 & 40.9 & 3.5 & 10.1 \\
November & 20.1 & 28.7 & 39.1 & 3.0 & 9.4 \\
December & 18.2 & 27.1 & 37.7 & 3.6 & 11.6 \\
\hline Annual & 17.0 & 28.0 & 42.4 & 3.5 & 14.0 \\
\hline
\end{tabular}


Table B-6

1991 PVUSA Maui Sovonics Array

Perfomance Data

\begin{tabular}{||lllllllll||}
\hline Month & $\begin{array}{l}\text { T Mod. } \\
\text { Wt. Avg. } \\
(\mathrm{C}) \text { ) }\end{array}$ & $\begin{array}{c}\text { POA } \\
\text { Insol. } \\
\left(\mathrm{kWh} / \mathrm{m}^{2}\right)\end{array}$ & $\begin{array}{c}\text { dc } \\
\text { Energy } \\
(\mathrm{kWh})\end{array}$ & $\begin{array}{c}\text { dc } \\
\text { Eff. } \\
(\%)\end{array}$ & $\begin{array}{l}\text { Max dc } \\
\text { Power } \\
(\mathrm{kW})\end{array}$ & $\begin{array}{c}\text { ac } \\
\text { Energy } \\
(\mathrm{kWh})\end{array}$ & $\begin{array}{c}\text { Max ac } \\
\text { Power } \\
(\mathrm{kW})\end{array}$ & $\begin{array}{c}\text { System } \\
\text { Avail. } \\
(\%)\end{array}$ \\
\hline January & 41.1 & 152 & 2373 & 3.1 & 19.6 & 2196 & 18.4 & 73 \\
February & 45.5 & 176 & 2877 & 3.3 & 20.6 & 2666 & 19.2 & 87 \\
March & 43.8 & 169 & 2830 & 3.4 & 20.1 & 2607 & 18.8 & 83 \\
April & 45.4 & 173 & 2864 & 3.3 & 20.3 & 2648 & 18.9 & 78 \\
May & 43.0 & 153 & 2760 & 3.6 & 19.1 & 2552 & 17.9 & 70 \\
June & 44.6 & 99 & 1526 & 3.1 & 18.1 & 1402 & 16.8 & 46 \\
July & 43.7 & 117 & 2082 & 3.6 & 18.0 & 1919 & 16.8 & 58 \\
August & 45.6 & 127 & 2248 & 3.6 & 18.4 & 2078 & 17.1 & 59 \\
September & 46.6 & 146 & 2390 & 3.3 & 18.5 & 2204 & 17.4 & 72 \\
October & 44.3 & 123 & 2184 & 3.6 & 19.3 & 2015 & 18.2 & 67 \\
November & 46.9 & 147 & 2510 & 3.5 & 17.5 & 2324 & 17.5 & 80 \\
December & 44.3 & 166 & 2916 & 3.6 & 18.0 & 2707 & 18.0 & 87 \\
\hline \hline
\end{tabular}


Appendix C

DETAILED 1991 O\&M SUMMARIES 


\section{DETAILED 1991 O\&M SUMMARIES}

Tables $\mathrm{C}-1$ through $\mathrm{C}-3$ summarize PVUSA's major O\&M activities at Davis. Table C-4 summarizes major O\&M activities for the Maui Sovonics array. (Some activities, such as washing arrays, do not interrupt plant performance.) The activities are defined as:

- Preventive maintenance (including planned outages)

- Failure-related (including forced outages)

- Research

\section{Table C-1}

1991 PVUSA Davis Preventive Maintenance

\begin{tabular}{||ll||}
\hline \multicolumn{1}{|c}{ Event } & \multicolumn{1}{c|}{ Date; Duration } \\
\hline PG\&E performed protective circuit functional tests on Solarex, UPG, & $1 / 24 ; 1$ day \\
ENTECH, and Photon Energy array PCUs & \\
PG\&E performed pre-parallel tests on SSI US-1 system (switchgear & $1 / 29,1 / 31 ; 1 / 2$ day ea. \\
passed, inverter failed) & \\
PG\&E performed two planned maintenance outages on $12 \mathrm{kV}$ grid & $1 / 8,3 / 12 ; 1 / 2$ day ea. \\
Visual inspection of arrays: front, back, and wiring & Weekly; $1 / 2$ hr ea. \\
ENTECH PCU calibration by PG\&E technicians and PVUSA staff & $4 / 10 ; 2$ days \\
ENTECH tracker clock, module position, NIP alignment, and stow battery & Monthly; 45 min ea. \\
inspection & \\
General EMT outage for 3-pole disconnect switch installation & $5 / 9 ; 1$ day \\
& $5 / 21 ; 4$ hrs \\
ENTECH array: clock replaced \\
tracking adjusted and battery serviced \\
battery serviced
\end{tabular}




\section{Table C-2}

1991 PVUSA Davis Failure-Related Activities

\begin{tabular}{|c|c|c|}
\hline \multicolumn{2}{|c|}{, Event } & Date; Duration \\
\hline \multicolumn{2}{|c|}{$\begin{array}{l}\text { PCU synchronization/sequencing/door interlock errors: UPG } 1 / 22,3 / 12,3 / 29,4 / 24,5 / 10, \\
5 / 13,7 / 10-11,7 / 15,7 / 25-26,7 / 31,9 / 26,9 / 30,10 / 26-27,12 / 18 \text {; Siemens } 3 / 4-6,3 / 30,4 / 1 \text {, } \\
7 / 2,10 / 20 ; \text { Solarex 4/6-8,4/18, 10/26-29; ENTECH 3/9-11, 3/25, 7/19-21, 12/14-20 }\end{array}$} & $\begin{array}{l}\text { Various dates; } 1 / 2 \\
\text { to } 3 \text { days }\end{array}$ \\
\hline \multicolumn{2}{|c|}{ DECC here to repair ENTECH PCU and work on sync errors on other EMT PCUs } & $4 / 3-5 ; 3$ days \\
\hline \multicolumn{2}{|c|}{ Six unscheduled site power outages; systems tripped off line } & $\begin{array}{l}5 / 18 ; 12 \text { hrs } \\
6 / 7 ; 1 / 2 \mathrm{hr} \\
8 / 30 ; \text { momentary } \\
8 / 31 ; \text { momentary } \\
10 / 31 ; 6 \text { hrs } \\
11 / 6 ; 11 \text { hrs }\end{array}$ \\
\hline \multirow[t]{2}{*}{ SSI: } & $\begin{array}{l}\text { array voltage imbalance - fuse failed } \\
\text { array thermocouple failure - new TC wired in (no effect on system } \\
\text { performance) }\end{array}$ & $\begin{array}{l}4 / 5-26 ; 4 \text { hrs repair } \\
6 / 19 ; 1 \text { day }\end{array}$ \\
\hline & module shattered by stray bullet from police target range & $\begin{array}{l}8 / 28-9 / 4 ; 8 \mathrm{hrs} \\
\text { total replacement } \\
\text { labor } \\
10 / 28 ; 4 \text { hrs }\end{array}$ \\
\hline \multirow[t]{4}{*}{ Sovonics: } & $\begin{array}{l}\text { module shorted (bubbled surface) - repair incl. I-V curves } \\
\text { array ground fault }\end{array}$ & $\begin{array}{l}6 / 10 ; 2 \text { hrs } \\
6 / 24-27 \\
\text { intermittent }\end{array}$ \\
\hline & array j-box fire (untesolved) & $\begin{array}{l}6 / 27 ; 10+\text { hrs } \\
\text { labor }\end{array}$ \\
\hline & $\begin{array}{l}\text { array ground fault (new power cable awaits j-box repair) } \\
\text { array j-box fire (re-design underway) }\end{array}$ & $\begin{array}{l}6 / 24 ; 8+\text { hrs } \\
6 / 27 ; 20+\text { hrs } \\
\text { team labor }\end{array}$ \\
\hline & six delaminating modules replaced & 12/10; 7 hrs \\
\hline UPG: & array panel replaced (had shattered back glass on module) & $11 / 27 ; 5$ hrs \\
\hline \multirow[t]{2}{*}{ Solarex: } & $\begin{array}{l}\text { PCU cumulative } \mathrm{kWh} \text { transducer wiring error fixed (off since array start in } \\
10 / 90 \text { ) } \\
\text { failed array source circuit connection repaired (troubleshooting on } 3 / 4,6,7 \text {; } \\
1 / 2 \text { day total) }\end{array}$ & $\begin{array}{l}3 / 6 ; 2 \text { hrs } \\
3 / 12 ; 2 \text { hrs }\end{array}$ \\
\hline & $\begin{array}{l}\text { PCU ac power transducer failure } \\
\text { array j-box loose wire } \\
\text { failed PCU push-on terminal replaced }\end{array}$ & $\begin{array}{l}6 / 8-12 ; 4 \text { hrs repair } \\
4 / 11 ; 2 \text { hrs } \\
10 / 26-29 ; 2 \text { hrs }\end{array}$ \\
\hline \multirow[t]{2}{*}{ ENTECH: } & $\begin{array}{l}\text { PCU: numerous troubleshooting attempts to get array to start up and peak } \\
\text { power track (unsuccesful, factory rep service call scheduled for April) } \\
\text { roll motor fuse replaced and roll drive mechanical interference remedied } \\
\text { controller clock date wrong (twice), reset }\end{array}$ & $\begin{array}{l}1 / 25,29,30,3 / 6 ; \sim 2 \\
\text { hrs ea. } \\
3 / 12 ; 1 / 2 \text { day } \\
6 / 29-7 / 1,9 / 3 ; 1 \mathrm{hr} \\
\text { ea. }\end{array}$ \\
\hline & $\begin{array}{l}\text { controller j-box wiring and fuse failure } \\
\text { PCU ac power transducer fuse blown } \\
\text { cable clamp replaced } \\
\text { tracking controller failure } \\
\text { wind speed sensor re-calibrated }\end{array}$ & $\begin{array}{l}7 / 4-5 ; 2 \text { hrs } \\
7 / 21-22 ; 1 \text { hr } \\
10 / 25 ; 2 \text { hrs } \\
12 / 30-1 / 7 / 92 ; 8 \text { hrs } \\
11 / 26 ; 2 \text { hrs }\end{array}$ \\
\hline
\end{tabular}


Table C-3

1991 PVUSA Davis Research Activities

\begin{tabular}{|c|c|}
\hline Event & Date; Duration \\
\hline I-V curves taken on SSI EMT-1 and US-1 Systems & $3 / 7 ; 1 / 2$ day \\
\hline Arrays washed & $6 / 6 ; 1$ day \\
\hline $\begin{array}{l}\text { EMT-1 PCU islanding tests (results showed PCUs could island indefinitely } \\
\text { under matched and near-matched loads - PG\&E is following up with } \\
\text { DECC/Helionetics) }\end{array}$ & $\begin{array}{l}8 / 20-21 ; 5 \text { people, } 1-1 / 2 \\
\text { days ea. }\end{array}$ \\
\hline Arrays washed in preparation for NREL photographer & $8 / 8 ; 1 \mathrm{hr}$ \\
\hline SSI EMT-1 array shut down for incidence angle and I-V curve tests & 10/8; 3 people, 8 hrs total \\
\hline
\end{tabular}

Table C-4

1991 PVUSA Maui Sovonics Array Failure-Related Activities

\begin{tabular}{|c|c|}
\hline Event & Date; Duration \\
\hline $\begin{array}{l}\text { Module junction box failures - } 11 \text { instances. In each case, the module had } \\
\text { to be replaced because of melted and corroded contacts. }\end{array}$ & $\begin{array}{l}1 / 91 \text { ( } 5 \text { mod.), } 3 / 91 \text { (1 } \\
\text { mod.), } 4 / 91 \text { ( } 1 \text { mod.), } \\
6 / 91 \text { ( } 2 \text { mod.), } 9 / 91 \text { (1 } \\
\text { mod.), } 12 / 91 \text { ( } 1 \text { mod.). } \\
\text { Typical } 4 \text { hrs labor per } \\
\text { repair trip to the remote } \\
\text { site. }\end{array}$ \\
\hline $\begin{array}{l}\text { PCU shutdown errors - } 32 \text { instances. Twelve of these coincided with a } \\
\text { known grid disturbance. On many occasions, the PCU indicated "dc } \\
\text { Overvoltage" as the cause for the trip. }\end{array}$ & $\begin{array}{l}\text { Various dates; durations } \\
\text { ranging from less than } 1 \\
\text { hour to as much as } 1 / 2 \\
\text { week. }\end{array}$ \\
\hline $\begin{array}{l}\text { Note: There were no preventive maintenance or research activities } \\
\text { reported during } 1991 \text { for the Maui array. }\end{array}$ & \\
\hline
\end{tabular}


Appendix D

PVUSA MAUI PARTICIPANTS 


\section{PVUSA MAUI PARTICIPANTS}

Department of Business, Economic Development \& Tourism

Maui Electric Company

Photovoltaics for Utility Scale Applications

Sovonics Solar Systems

Maui Economic Development Board

Energy Conversion Devices

U.S. Department of Energy 
Appendix $\mathrm{E}$

TECHNOLOGY TRANSFER ACTIVITIES 


\section{TECHNOLOGY TRANSFER ACTIVITIES}

Appendix E includes a list of technology transfer activities, including papers, presentations, and visitors to the Davis site.

\section{MEETNGS, CLASSES, AND AWARDS}

On January 15 to 18 , PVUSA hosted a joint meeting with the U.S. Technical Advisory Group of the IEC Technical Committee 82 on Solar PV Energy Systems, and the IEEE Standards Coordinating Committee 21 (Photovoltaics). These groups are responsible for developing international and domestic standards for PV. The committees discussed standards for module and system testing (both performance and qualification) and for estimating performance.

At the request of the PVUSA Steering Committee, the Solar Energy Industries Association (SEIA) hosted a meeting in May for representatives of the PV industry involved in PVUSA to discuss Phase 2 of the project.

In August, PVUSA received a 1991 Environmental Achievement Special Merit Award from the National Environmental Awards Council of Washington, D.C.

In September, the Davis site sponsored a Red Cross-certified CPR class for nine project team members. Each member received a Red Cross Certificate of Training.

In October, PVUSA hosted a meeting of the IEC Technical Committee 82. Working Group 3 of this committee (which includes representatives from Canada, Germany, Italy, Japan, Switzerland, the United States, and other countries) works on international standards for photovoltaic systems. PG\&E is represented on these standards committees to provide a utility perspective and to relate experience from PVUSA and PG\&E's PV Test Facility.

\section{PAPERS AND PRESENTATIONS}

Steve Hester gave a presentation titled "PVUSA Progress Update" at the SOLTECH 91 conference in Burlingame, California on March 26.

PVUSA hosted a Technology Transfer meeting and tour of the Davis site on March 28 in conjunction with the SOLTECH 91 conference held in Burlingame, California. Two buses carried 59 participants to the site for a guided tour. During the two-hour ride to the site, a technology transfer presentation was given by project 
personnel. The return trip included a question-and-answer discussion, and participants were asked to complete a questionnaire about PVUSA.

In April, Tammie Candelario gave a presentation titled "Experience Gained from the First Three Years of the PVUSA Project (1988-1990)" at the 1991 American Power Conierence in Chicago, Illinois.

In May, PVUSA issued the 1989-1990 PVUSA Progress Report. The report includes information on PVUSA's organization, photovoltaic and engineering standards, lessons learned from procurement and construction, factory and field qualification test results, and performance and O\&M data.

In August, PVUSA participated in the 1991 International Solar Energy Society (ISES) Solar World Congress in Denver, Colorado. Tim Townsend presented a paper titled "PVUSA: Two Years of Operating Experience."

In October, Tammie Candelario presented a paper titled "PVUSA--Performance, Experience, and Cost" at the 22nd IEEE PV Specialists Conference in Las Vegas, Nevada. Several other project team members attended the conference, and Project Manager Steve Hester chaired two sessions on terrestrial photovoltaic systems.

\section{STE TOURS}

The following visitors were at the Davis site for tours or special project meetings:

\section{January}

- Tim Leong, PG\&E News Department, with Steve Strid, Tomorrow magazine

- Marvin and Karen Silver, PG\&E contract photographers, Mariposa, California

- Carol Morton, UC-Davis News Service, with Dr. Satofuka and seven others from Tokyo Broadcast System (TBS)

- Jay Chamberlin, Sandia

- Alessandro Saragosa, photojournalist, Italy

- M. Varadarajan, Suryovonics Limited, India, with Thodus Hamashree, Fremont, California, and John Furber, La Honda, California

- Visitors from PV standards meeting in San Ramon: Jerry Anderson, SSl; Arne Nilsson, NIFE; Paul Russell and Steve Chalmers, consultants; Robert Klein, SEIAIEEE; David Feder, Electrochemical Energy Storage Systems, Inc.; Laxmi Mrig, NREL; and Paul Taylor, APS

- Anne Grete Hestnes, University of Trondheim, Norway, and Fritjof Salvesen, Royal Norwegian Council for Scientific and Industrial Research

- Salvatore Barbaro, Carlo Gallucci, Ignazio Lippolis, and interpreter, Italy

- Three representatives of Nissin Electric and one representative of Kansai Electric, Japan

- Darrell Nystrom, PG\&E (W6EYU), with guest (KGGLV)

- Kay Halpern, U.S. General Accounting Office, with David Anderson, Geothermal Resources Council, Davis 


\section{February}

- Margie Whipple, Sandia

- Hon. R.H. Kaijuka, and Betty Katsiiuberzi, Ministry of Energy, Uganda

- Don Greenbaum, PG\&E, with Kim Rosmaier and Elaine Hebert, UC-Davis

- Kevin Matthews, Max Media Lid., Canada

- Allan Walton, James Cook University, Australia

- Wilfred Ullrich, Canada, with Theo Manos, Dallas, Texas

- Three PG\&E Electric Resources Planning Department representatives

- Darlene Sherman, Davis

- T. Ohno, and M. Ohta, New Energy and Industrial Technology Development Organization (NEDO), Japan

\section{March}

- Walt Whittenton, Marysville, California

- Louie Fisara, Davis

- Warren Cooley, Davis

- Faula Speers and Krista Buhr, Bain \& Co.

- Jake Brooks, Independent Power Producers Society of Ontario (IPPSO), Canada

- Mark Farber, MSEC

- Harry Reamers, Bureau of Reclamation, Denver, Colorado

- Richard King, DOE

- Approximately ten German visitors from the UC-Davis International House

- Janusz Molinski, photographer, Australia

- Lloyd Herwig, DOE

- Approximately 65 visitors affiliated with the SOLTECH 91 conference

- Sabine Busching, Technische Universität, and Helmut Jäger, Solvis Energiesysteme, Germany

April

- Marilyn Duncan and Dr. Graham Redding, Renewable Energy Authority Victoria, Australia, with Jim Miwa, CEC

- David Schwarzbac

- Mark Farber, Lowell Spicer, and Dick Pilo, MSEC

- Gene Karas, instructor, with four students from Analy High School, Sebastopol, California, with Duke McGonegle, PG\&E Santa Rosa office

- Warren Cooley, Davis

- Brenda Hanschen and Pat Schaub, PG\&E

- Four Japanese TV station representatives with Don Greenbaum, PG\&E

- José J. Juan Villa and Enrique Medina Valcárcel, Spain 
May

- Graydon John Forrer, U.S. Congress subcommittee counsel, with Rich McCamish, PG\&E Governmental Relations

- Mike Mason, South San Francisco

- Jerry Kaplan, Dancing Bear Honey

- David Brandenburger, Sacramento high school student, and Don Greenbaum, PG\&E

- John Tripp, Sheet Metal Workers Union business representative

June

- Lee Raner and Rich Storamoski, PG\&E

- Fouad Dagher and Moneer Azzam, MSEC

- Don Warembourg and Gary Liljenberg. Public Service of Colorado

- Chris Sherry and six other representatives from APS

- Steven Strong and Robert Wills, Solar Design Associates

- John Prescott and Michael Youngblood, Idaho Power, with Steve McLean, PG\&E R\&D

- Mr. and Mrs. Wellington Scott, photographers, Walnut Creek, California

- Gina Cioffi, reporter for the Fairfield, California Daily Republic

- Mr. Matsuo, Japan Scientific American, and Mike Ikeda, 3T Co.

- Max Little, Bechtel

- Gene Keller, PG\&E Mktg., with 24 PG\&E commercial customers

July

- Brian Glenn, Jon Bush, and Brian Vick, Goldstar Industries

- Nadine Wong, student, Princeton University

- Rosita Royeca and Heinz-Wolfgang Boehnke, Philippine-German Special Energy Program

- Heinz Plosita

- Luiz Antonio Prado, Collett \& Sons, Rio De Janeiro, Brazil

- Charles Leigh and Michel Lebeuf, Hydro Quebec, Canada

- Bill White, Bechtel R\&D, with Walt Stolte, Bechtel

- Tony Bennett, DOE

- Leon McFadden and Joe Baker, Liberty Painting

- Gregory Kiss, KCA (architect for APS)

- Don Greenbaum, PG\&E, with visitors from Woodland, California, and Germany

- Fred Chapman, Davis

- Five visitors from Japan's NHK Educational Corporation and one from South Bay Broadcasting, California (to do a TV spot)

- Arthur Lilley, Westinghouse, and Doug Danley, IPC

- Parker Mathusa, NYSERDA's PVUSA SC representative

- Biff Hoffman, Salt River Project, with Ernie Palomino, SRP's PVUSA TRC rep.

- Norman Rogers

- Eight visitors from ABB Impell Corporation and Lawrence Livermore National Laboratory 
- Pierre-Alain Bruchez, Département de l'Economie Publique, Switzerland

- Mitsuyuki Iwakata, VP United Solar Systems Corp., with four others from Canon

\section{August}

- Richard Hirsch, professor, Virginia Polytechnic Institute

- Warren Gretz, photographer for NREL

- Larry Slominski and Prem Nath, USSC

- William McCartney and Gregory Carreras, Sacramento Unitarian Church

- Approximately six people attending a PVUSA US-2 pre-bid meeting

- Gian Nicola Belcastro and Alberto lliceto, ENEL, Italy

- Christophe Girardier, France

- Peter Lund, Finland

- Jim Bing, researcher, University of Lowell

- Richard Gottlieb, Sunnyside Solar Inc.

- Wes Stein, New South Wales Energy Commission, Australia

- Peter Aschenbrenner, SSI

- Jim Kennedy and Mike Schumaker, GAO, with David Morris, California Public Utilities Commission

- Three visitors from PG\&E Transmission Planning

- Thirty-five teachers on a PG\&E-sponsored visit

- One unknown visitor from Japan (August 23rd)

- David Thompson, National Cooperative Business Association, with three visitors from Japan

- Yasuko Yamamoto, Com Tour Center, Inc., with fifteen visitors from Tokyo, Japan

- Rochelle Gauthier and Steve Selee, Optical Coating Laboratory, Inc., Santa Rosa, California

- Approximately one dozen people attending a PVUSA EMT-3 pre-bid meeting

- Miriam Jang, International House, Davis, with two Japanese visitors

- Three representatives from NEDO, Japan, with one host from 3T \& Associates, Glendale, California

- Yolo County Sheriff's Department deputy

- Lt. Sackett, Davis P.D.

\section{September}

- Don Greenbaum, PG\&E, with Phil Coleman, Davis Chief of Police, and John Meyer, Davis City Manager

- John Johansen and Lynne Fosburgh, Photon Energy, with four visitors from Golden Technologies Company Inc.

- Ghulam M. Nurie, GMN Enterprises, Fremont, California, with Larry Yeakel, architect, Del Mar, California

- Paul-Georg Gutermuth, German Federal Ministry of Economics, and Annie Sarre, German Aerospace Research Establishment

- Eight visitors from the Shandong Academy of Science, China

- Antoine Bonduelle, Editor, French energy magazine

- Peter Aschenbrenner, with six others from SSI

- Linda Joy DeBoard, CEC, with five visitors from China 
- Miriam Jang, International House, Davis, with 12 visitors from the Humphrey Scholar program (representing Morocco, Cote D'Ivoire, Israel, Bangladesh, Sri Lanka, Kenya, Zaire, Ethiopia, Thailand, Guyana, and Sierra Leone)

- Naoto Fukuyama, Tokyo Electric Power Company

- Hirofumi Fujii and four camera operators from IMAX Co., Ltd., for USSC

- Manired van Eyk, journalist, Holland, and Laura Perez, journalist, Mexico

- David Thompson, National Cooperative Business Association, with Yuko Hasegawa, Seikatsu Club Consumers' Co-Operative, Japan

- Linda Joy DeBoard, CEC, with Lenox Brown and Joseph Daniel, Montserrat

\section{October}

- Pat and Charlie Schaller, Waukegan, Illinois

- Dr. Martin Green and five others from the University of New South Wales, Australia

- Dr. Robert Walters, ENTECH; with Paul Jaster, 3M Solar Optics - St. Paul, Minnesota; Michael Wong, M. Global Arbitrage - Hong Kong; and Randy Hella, STERNCO - Minneapolis, Minnesota

- David Deng, Guangdong Group Ltd., China

- Robert Lopez Puckett, Solar Electric Company, Philippines

- Dr. Armin Räuber, Fraunhofer Institute for Solar Energy Systems, Germany

- Dr. Chun Tsai, National Chiao Tung University, Taiwan ROC

- David Braga, Hong Kong

- Dick Hourigan, PG\&E, with 25 PG\&E commercial account customers

- Robert Mathews, PG\&E R\&D

- Toshi Ehata, 3T \& Associates, with two representatives from Okinawa Electric Power Co. and one from Osaka Gas Co., Japan

- Miriam Jang, Davis International House, with Kozuka Hisao and Yuko Hasegawa, representing Japanese co-ops

- Werner Knaupp, Germany

- Dave Collier, Gary Hodges, and Eric Haemer, Sacramento Municipal Utility District (SMUD)

- Twenty-one visitors from the electric utility Fynsvaerket, Denmark

- Eight visitors from the IEC Technical Committee 82

- Nine representatives from the Japanese Electrical Manufacturers Association (JEMA)

- Miriam Jang, Davis International House, with five German visitors

- Four photographers from Canon, inc.

- Twenty-five students from Sonoma State University

- Mark Mares, Laura Becker, and Russell Perrin, DOE Controller/Budget office, and Debbie Perrin, Washington, DC

- John Johansen, Photon Energy

- Thomas Wegemer and Ralph Buscher, Static Power Conversion

- Hugh McDermott, RCG/Hagler, Bailly, Inc. - San Francisco, with four visitors from Egypt

- Four representatives from Toshiba and the Tokyo Electric Power Co., Japan 


\section{November}

- David Thompson, National Cooperative Business Association, with approximately 10 visitors from Swedish co-ops

- Chuck McGowin and Terry Peterson, EPRl, with Lori Adkins and Ronald Sinton, SunPower

- Spencer Taylor and Mark Farber, MSEC

- Dick Hourigan, PG\&E, with a PG\&E-sponsored tour group

- Keijo Mutanen, Finland

- Terry Ewing, CEC, with two Soviet visitors, two from Flowind, and one from Scholfield Solar

- Dick Hourigan, PG\&E, with a group of 40 students from a Pacifica, California high school

- Linda Joy DeBoard, CEC, with a group of 25 people from Corsica

\section{December}

- Rick Schmidt, Hollister, California

- Miriam Jang, Davis International House, with six German visitors

- Garth Hall, assistant to PG\&E CEO Stan Skinner

- Gary Wiens, Jim Salomone, Mike Jennings, and Raymond Marciano, PG\&E Fresno operations; and Jim Gartong, Greenleaf Consulting, Fresno

- DOE Safety Audit attendees Lewis Jacobson and Paul Moskowitz, Brookhaven National Laboratory; Alec Bulawka, DOE; Jim Garrett, Reynolds Electric \& Engr.; and Rick Tyler, CEC

- U.S. Congressman Scheuer (NY), and three congressional staff members representing himself and Congressman Ritter (PA), with Katie McCormack, PG\&E R\&D

- Tracey Buck-Walsh, CEC

- Mr. and Mrs. Robert Schauer, SunPower Corp.

- Ellen Plaza, Photocomm 
Appendix $F$

TERMS AND ABBREVIATIONS 


\section{TERMS AND ABBREVIATIONS}

APS

Availability

BOS

Capacity Factor

CEC

DAS

DECC

DOE

Efficiency

EMT

EPPI

IPC

MSEC

NREL
Advanced Photovoltaic Systems, Inc.

Percentage of daytime hours during which a system's ac power output exceeds $0.1 \mathrm{~kW}$.

Balance of System. All equipment and associated labor not part of the actual PV array, - such as the support structure, power conditioning unit, and utility grid interconnection equipment.

Ratio of monthly ac energy $(\mathrm{kWh})$ divided by the product of the ac rating $(\mathrm{kW})$ and the number of hours per month.

California Energy Commission.

Data Acquisition System.

Deita Electronic Control Corporation.

U.S. Department of Energy.

Ratio of monthly dc energy produced to monthly POA insolation during hours when the $\mathrm{PCU}$ is operating.

Emerging Module Technology.

Electric Power Research Institute.

Integrated Power Corporation.

Mobil Solar Energy Corporation.

National Renewable Energy Laboratory. 
NYSERDA

PCU

PG\&E

POA

PTC

SC

SSI

STC

TRC

UPG

US
New York State Energy Research and Development Authority.

Power Conditioning Unit. Contains a dc-to-ac inverter, system protection and control, and maximum power tracking circuits.

Pacific Gas \& Electric.

Plane of Array.

PVUSA Test Conditions. Defined as $1000 \mathrm{~W} / \mathrm{m}^{2}$ POA irradiance for flat plate modules, 850 $\mathrm{W} / \mathrm{m}^{2}$ direct normal irradiance for concentrators, $20^{\circ} \mathrm{C}$ ambient temperature, and $1 \mathrm{~m} / \mathrm{s}$ wind speed.

PVUSA Steering Committee.

Siemens Solar Industries, Inc.

Standard Test Conditions. Defined as $1000 \mathrm{~W} / \mathrm{m}^{2}$ POA irradiance for flat plate modules, $850 \mathrm{~W} / \mathrm{m}^{2}$ direct normal irradiance for concentrators, $25^{\circ}$ or $28^{\circ} \mathrm{C}$ cell temperature, and air mass 1.5 spectrum.

PVUSA Technical Review Committee.

Utility Power Group.

Utility Scale. 